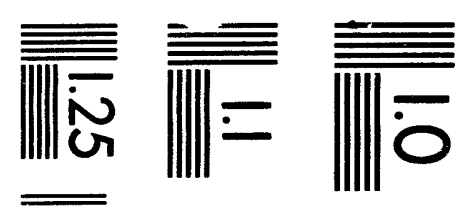

IIIII六

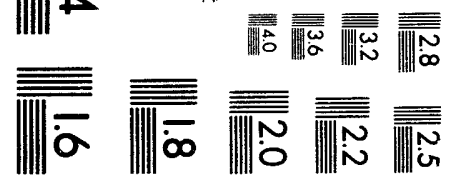



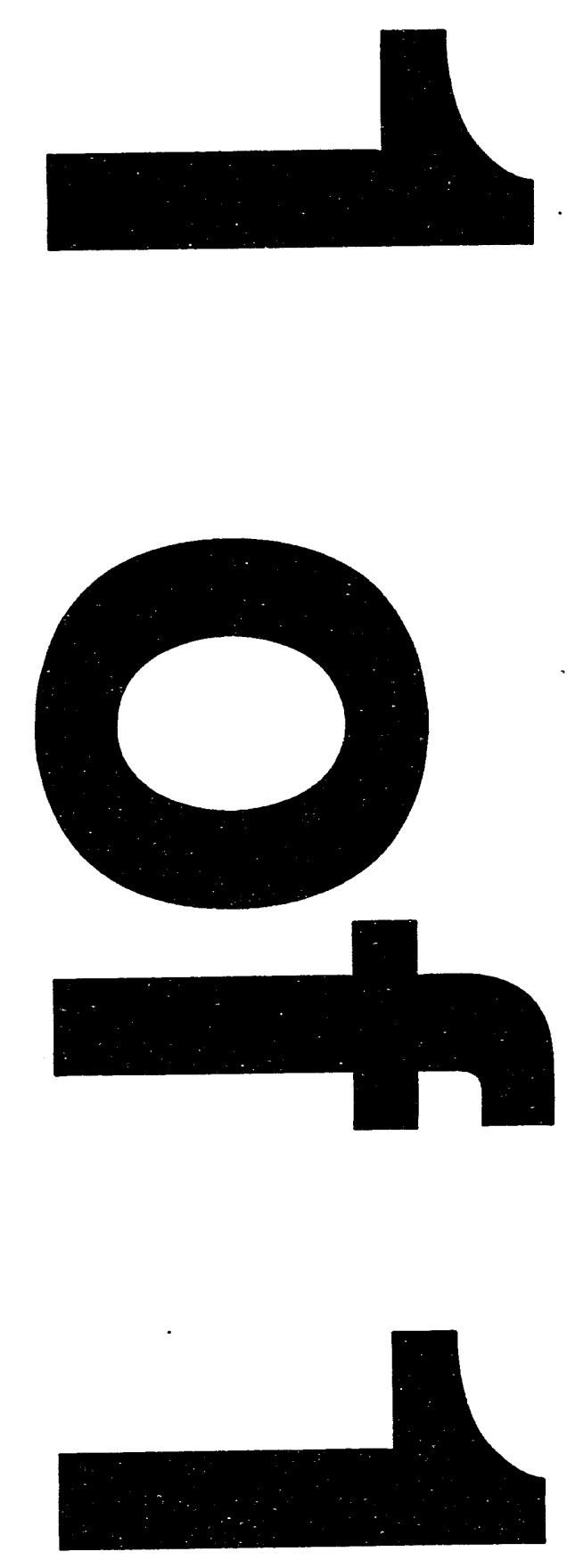
UCRL-LR-115188

Distribution Category UC-712

\title{
Radiological Analysis of the National Ignition Facility
}

\author{
M. S. Singh
}

October 26, 1993

LAWRENCE LIVERMORE NATIONAL LABORATORY

University of California $\bullet$ Livermore, California $\bullet 94550$

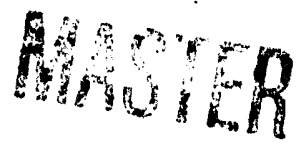




\section{Contents}

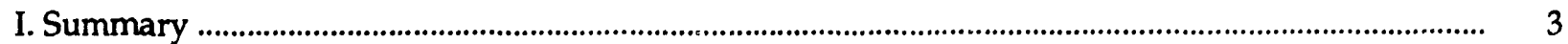

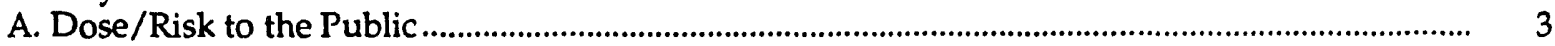

B. Collective Population Dose and Health Effects ......................................................................................

C. Radiation Intensities at the Site Boundary ........................................................................................ 3

D. Occupational Exposure Rates .............................................................................................................. 4

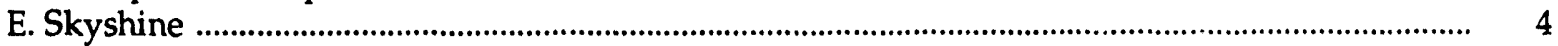

F. Atmospheric Transport Code Validation ................................................................................... 4

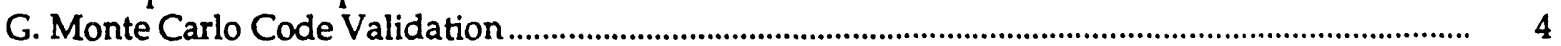

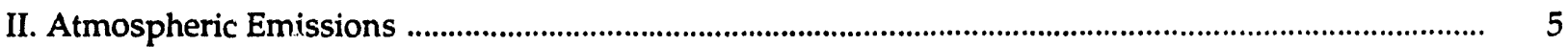

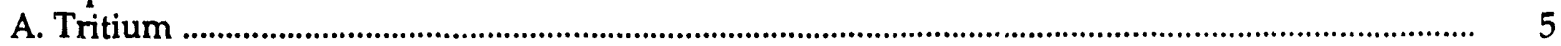

B. Environmental Monitoring for Air Emissions ................................................................................

C. Air Activation .................................................................................................................................... 11

III. Neutron Skyshine and Direct Radiation ........................................................................................ 15

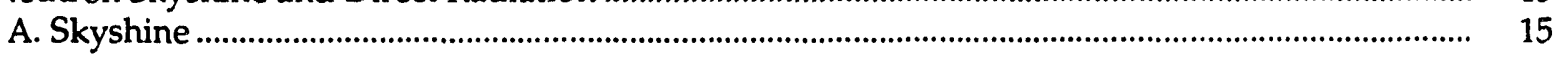

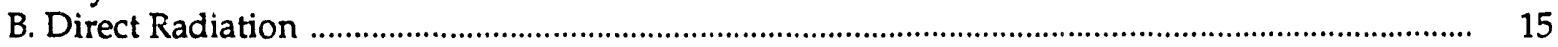

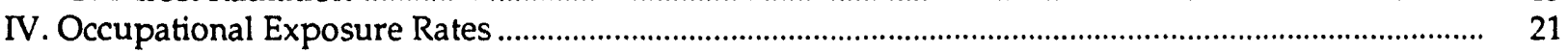

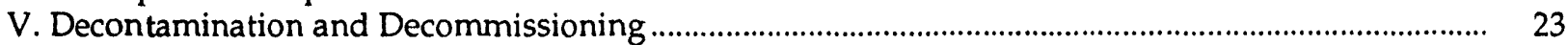

VI. Environmental Transport of Tritium: Validation of the EPA CAP88-PC Code .................................... 25

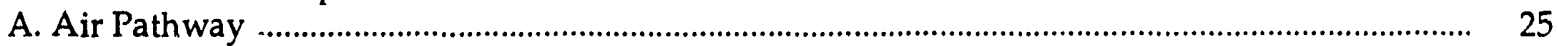

B. Tritiated Water Vapor Emissions ................................................................................................... 28

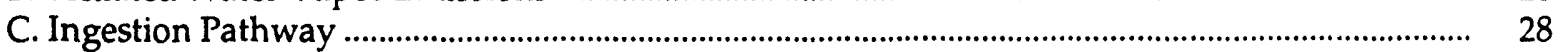

VII. Benchmark Shielding Calculations and Measurements for Deep Penetration of

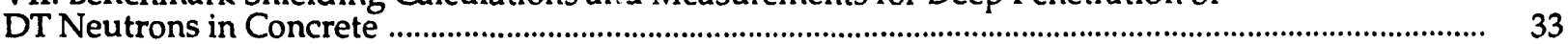

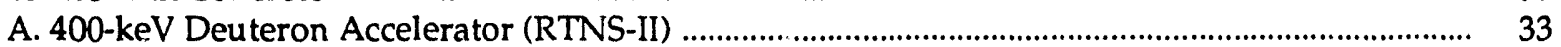

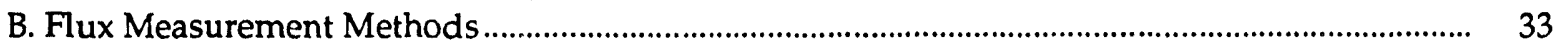

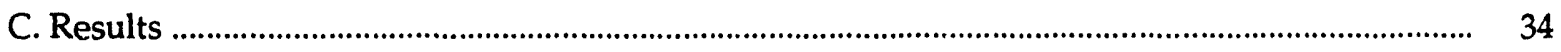

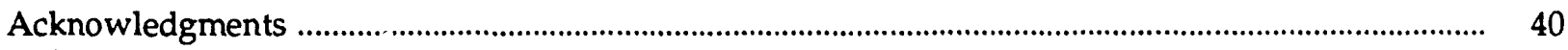

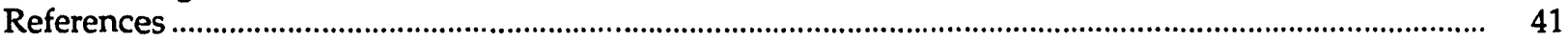




\title{
Radiological Analysis of the National Ignition Facility
}

\begin{abstract}
The National Ignition Facility (NIF) will be capable of providing a laser output pulse at $0.35 \mu \mathrm{m}$ wavelength with an energy of $1.8 \mathrm{MJ}$ and a power of $500 \mathrm{TW}$. The NIF will house a multi-beamline, Nd-doped-glass laser capable of delivering such pulses into a target chamber. In the target chamber, a positioner will center a target containing fusion fuel (a deuterium-tritium mixture) for each ignition shot. Diagnostics in the chamber will provide the test data (e.g., neutron and $x$-ray yields). The NIF baseline case would result in deuterium-tritium (DT) neutron yields of about $10^{16}$ to $10^{19}$ per fusion shot. The baseline fusion shots would use $2 \mathrm{Ci}$ of tritium per capsule, with an annual input of about $600 \mathrm{Ci}(60 \mathrm{mg})$. The resulting anticipated annual airborne emissions would consist of approximately $10 \mathrm{Ci}$ of tritium and small amounts of activated air species. The NIF shielding configuration would limit the direct and skyshine radiation intensities around the facility to less than $0.1 \mathrm{rem} / \mathrm{y}$ on site and to less than $0.001 \mathrm{rem} / \mathrm{y}$ off site. This report presents the results of atmospheric transport calculations for tritium and activated air emissions; neutron and secondary gamma-ray shielding calculations; and results of benchmark studies for validating the EPA CAP88-PC code (for the transport of tritium) and the Lawrence Livermore National Laboratory neutron-photon transport code TART. All calculations were normalized to the annual baseline case of $1.4 \times 10^{20}$ DT-fusion neutrons. Tritium emissions were normalized to $10 \mathrm{Ci} / \mathrm{y}$. Radiological analyses show that normal NIF operations would result in off-site radiation intensities that would represent insignificant increases over the natural background radiation intensity. The NIF is a national facility, and the DOE has not completed the site evaluation process. Although the results presented in this report are for LLNL, the analytical approach is applicable to any site.
\end{abstract}




\section{Summary}

The following major conclusions can be drawn from this report:

\section{A. Dose/Risk to the Public}

During normal NIF operations, small amounts of tritium and activated air products would be released into the atmosphere. Based on calculations and past experience, the expected annual emissions resulting from fusion experiments would be as follows:

- ${ }^{3} \mathrm{H}, 10 \mathrm{Ci}$.

- ${ }^{13} \mathrm{~N}, 18.5 \mathrm{Ci}$.

- $16 \mathrm{~N}, 35 \mathrm{Ci}$

- ${ }^{17} \mathrm{~S}, 0.29 \mathrm{Ci}$.

- ${ }^{40} \mathrm{Cl}, 0.31 \mathrm{Ci}$.

- ${ }^{41} \mathrm{Ar}, 3.28 \mathrm{Ci}$.

- ${ }^{14} \mathrm{C}, 9.25 \times 10^{-5} \mathrm{Ci}$.

Table 1 gives the effective dose equivalent and potential health effects to a maximally exposed member of the public from these emissions. The dose rate to a maximally exposed person would be $7.5 \times 10^{-6} \mathrm{rem} / \mathrm{y}$, and the corresponding risk of fatal cancer would be $3.8 \times 10^{-9}$ per year. This added exposure rate would be insignificant in relation to both the natural background radiation intensity of 0.3 $\mathrm{rem} / \mathrm{y}$ and the DOE/EPA air emission standard of $0.01 \mathrm{rem} / \mathrm{y}$. Similarly, the increase in individual fatal cancer risk would be insignificant in relation to the natural fatal cancer incidence rate of $1.96 \times 10^{-3}$ per year.

\section{B. Collective Population Dose and Health Effects}

Table 1 also gives the projected dose and health effects for the year-2000 population residing within $80-\mathrm{km}$ radius of Lawrence Livermore National Laboratory (LLNL). The collective dose rate of 0.14 person-rem/y shown in Table 1 is insignificant in relation to the $2.3 \times$ $10^{6}$ person-rem/y natural background dose rate received collectively by the same population. The average dose rate to the population would be $1.9 \times 10^{-8} \mathrm{rem} / \mathrm{y}$, which is $6 \times 10^{-8}$ times the natural background intensity. A collective dose rate of 0.14 person-rem $/ y$ would result in $7 \times 10^{-5}$ extra fatal cancers over the lifetime of the exposed population per year of NIF operation, again $6 \times$ $10^{-8}$ times the value expected from natural background radiation.

\section{Radiation Intensities at the Site Boundary}

The projected radiation intensity from all sources (of which the greatest contributor is skyshine) at the closest site boundary due to normal NIF operations would be about $1.3 \times$ $10^{-4} \mathrm{rem} / \mathrm{y}$ (see Table 2), an insignificant addition to the natural background intensity.

Table 1. Projected off-site individual and population dose and potential radiologically related health risks resulting from NIF air effluents.

\begin{tabular}{|c|c|c|c|c|c|}
\hline \multirow[b]{2}{*}{ Exposure category } & \multicolumn{2}{|c|}{ NIF operation } & \multicolumn{3}{|c|}{ Natural background } \\
\hline & $\begin{array}{c}\text { Dose rate } \\
\text { (rem/y) }\end{array}$ & $\begin{array}{c}\text { Fatal cancer risk } \\
\text { (deaths/y) }\end{array}$ & $\begin{array}{c}\text { Dose rate } \\
\text { (rem/y) }\end{array}$ & $\begin{array}{c}\text { Fatal cancer } \\
\text { risk (deaths/y) }\end{array}$ & $\begin{array}{c}\text { Total } \\
\text { deaths } / y^{a}\end{array}$ \\
\hline Maximally exposed person & 7.5E-6 & $3.8 \mathrm{E}-9$ & 0.3 & $1.5 \mathrm{E}-4$ & $1.96 \mathrm{E}-3$ \\
\hline \multicolumn{6}{|l|}{ Population within $80 \mathrm{~km}$} \\
\hline Collective & 0.14 & $-0 \mathrm{E}-5$ & $2.3 \mathrm{E} 6$ & 1.1E3 & $1.5 \mathrm{E} 4$ \\
\hline Average & $1.9 \mathrm{E}-8$ & $9.3 \mathrm{E}-12$ & 0.3 & $1.5 \mathrm{E}-4$ & $1.96 \mathrm{E}-3$ \\
\hline
\end{tabular}

a Based on the average cancer death rate in the United States (Moore, 1993). Since the California rate is 1.53 deaths per 1000 (Moore, 1993), about 12,000 annual natural cancer deaths would be expected for the year 2000 for the population within an $80-\mathrm{km}$ radius of LLNL. 
Table 2. Projected radiation exposure rates $330 \mathrm{~m}$ north of the NIF (assumed distance to nearest site boundary).

\begin{tabular}{lccc}
\hline Radiation & $\begin{array}{c}\text { Effective } \\
\text { dose rate } \\
\text { (rem/y) }\end{array}$ & $\begin{array}{c}\text { DOE/EPA } \\
\text { standard } \\
\text { (rem/y) }\end{array}$ & $\begin{array}{c}\% \text { of } \\
\text { standard }\end{array}$ \\
\hline Air effluents & $\mathbf{0 . 0 0 0 0 0 6}$ & 0.01 & 0.06 \\
Direct/skyshine & $\mathbf{0 . 0 0 0 1 2}$ & - & - \\
Total & $\mathbf{0 . 0 0 0 1 3 ^ { \mathrm { a } }}$ & 0.1 & $\mathbf{0 . 1 3}$ \\
\hline
\end{tabular}

a Total effective dose rate at the nearest site boundary would be indistinguishable from the average natural background radiation intensity, which is about $0.3 \mathrm{rem} / \mathrm{y}$.

\section{Occupational Exposure Rates}

The residual radioactivity in various structural components of the target chamber, space frame, concrete, and optics, and the residual activation products and tritium in the chamber, would together constitute the primary sources of occupational exposure. As shown in Table 3, the occupational doses will be kept at least an order of magnitude lower than the current DOE administrative guide and the projected DOE/ICRP radiation standards.

\section{E. Skyshine}

For a $1.22-\mathrm{m}$-thick concrete roof, the neutron and gamma-ray skyshine dose rate at the nearest site boundary (fence post) would be about 0.00012 $\mathrm{rem} / \mathrm{y}$ for an annual yield of $1.4 \times 10^{20}$ neutrons. This dose rate is insignificant in relation to the DOE/ICRP limit of $0.1 \mathrm{rem} / \mathrm{y}$ to members of the public. A cost-benefit analysis will be performed to optimize the target room shielding configuration. For instance, an additional 0.3 -m-thick concrete roof would reduce the skyshine dose by more than a factor of 10 .

\section{F. Atmospheric Transport Code Validation}

We have conducted benchmark studies that indicate that the CAP88-PC transport code is likely to overpredict tritium concentrations in the Livermore Valley by a factor of 1.1 to 3.2. This agreement between the measured and predicted results is quite remarkable given the complexity of transport processes and of meteorological and terrain conditions.

\section{G. Monte Carlo Code Validation}

Theoretical and experimental data indicate that (when particles are properly weighted in the problem) the neutron-photon transport code TART tends to overpredict transmission in the forward direction by a factor of 2 for very thick ( 2 to $2.5 \mathrm{~m}$ ) concrete shields. The actual effectiveness provided by concrete shielding would therefore be greater than that based on TART calculations.

Details regarding atmospheric tritium and activated air emissions, dose calculations, shielding calculations, and benchmark studies are presented in the following sections. Neutronics for the NIF are also discussed in a separate document (Latkowski and Tobin, 1993). Selection of nuclear radiation shielding materials around the NIF vacuum chamber that would provide attenuation equivalent to $30 \mathrm{~cm}$ of polyethylene will be discussed in a separate document. The radiation detection and measurement instrumentation that will be used to validate projected exposure rates and airborne radioactivity concentrations will be listed in the NIF Siting Requirement Document.

Table 3. Projected occupational radiation doses from normal NIF operations.

\begin{tabular}{llcl}
\hline $\begin{array}{l}\text { Exposure } \\
\text { category }\end{array}$ & $\begin{array}{c}\text { Effective } \\
\text { dose rate } \\
\text { (rem/y) }\end{array}$ & $\begin{array}{c}\text { standard } \\
\text { (rem/y) }\end{array}$ & $\begin{array}{c}\text { \% of } \\
\text { standard }\end{array}$ \\
\hline $\begin{array}{l}\text { Prompt } \\
\begin{array}{l}\text { Residual activity } \\
\text { (design criteria) }\end{array}\end{array}$ & 0.01 & - & - \\
Tritium & 0.18 & - & - \\
Total & 0.01 & - & - \\
\hline a DOE 5480.11, 5 rem/y (occupational limit); ICRP 60,2 rem/y \\
(recommended average over 5-ycar period).
\end{tabular}




\section{Atmospheric Emissions}

The National Ignition Facility will conduct several hundred fusion experiments per year to achieve ignition and gain. Experiments with DT shots can result in atmospheric releases of small amounts of tritium (primarily during cleanup) and activated air from the target room. Table 4 summarizes exposure rates from postulated tritium and activated-air emissions. Code validation studies indicate that the dose estimates given in Table 4 are overpredicted on the average by a factor of 1.1 to 3.2. As shown in Table 4, the projected maximum and average exposure rates are well below the EPA air emission standard of $0.01 \mathrm{rem} / \mathrm{y}$. Emissions at these intensities will have negligible added impact on the environment and human health, so LLNL's existing environ-

Table 4. Projected exposure rates for the year 2000 due to postulated annual tritium and activated-air emissions from NIF operations.

\begin{tabular}{lcc}
\hline Emission & \multicolumn{2}{c}{ Effective dose equivalent } \\
\cline { 2 - 3 } & $\begin{array}{c}\text { Individual } \\
\text { (rem/y) }^{\mathrm{a}}\end{array}$ & $\begin{array}{c}\text { Population } \\
\text { (person-rem) }^{\mathrm{b}}\end{array}$ \\
\hline Tritium $^{\mathrm{c}}$ & $9.2 \mathrm{E}-7$ & $1.3 \mathrm{E}-1$ \\
Activated air & $6.6 \mathrm{E}-6$ & $1.2 \mathrm{E}-2$ \\
Total & $7.5 \mathrm{E}-6^{\mathrm{d}}$ & $1.4 \mathrm{E}-1^{\mathrm{e}}$ \\
\hline
\end{tabular}

a Maximum potential dose equivalent from all exposure pathways to a member of the public living $0.8 \mathrm{~km}$ NNE of LLNL Bldg. 391.

b Dose equivalent for the projected population (7.56 million) living within an $80-\mathrm{km}$ radius of LLNL. c Tritium emissions will occur primarily during cleanup. The expected emissions will be less than $1 \%$ of past annual emissions from LLNL and SNL, (see Table 15), and will be about the same as those experienced at the first JET tritium experiment, conducted in November 1991. The air activated species are assumed to be purged at a rate of $1 \%$ of the target room volume per minute, the same rate that was designed for the Nova laser. Based on the openings in the target chamber for laser beams and diagnostics, about $13 \%$ of the primary neutrons leak into the target room. The neutron-induced radioactivity is normalized to $1.4 \times 10^{20} \mathrm{DT}$ neutrons.

d Calculated lifetime fatal cancer risk for the maximally exposed individual for a lifetime $(70 \mathrm{y})$ continuous exposure is $2.6 \times 10^{-7}$.

e Calculated collective population health risk (deaths/y) is $7.0 \times 10^{-5}$; average individual risk is $9.3 \times 10^{-12}$. Average dose rate for the population is $1.9 \times 10^{-8} \mathrm{rem} / \mathrm{y}$, approximately $0.000006 \%$ of the natural background radiation intensity. mental monitoring program would provide more than adequate coverage for NIF operations.

\section{A. Tritium}

Each DT filled capsule will contain less than $0.2 \mathrm{mg}$ of tritium, so the annual tritium input to the NIF would be about $60 \mathrm{mg}(600 \mathrm{Ci})$. With proper containment and scrubbing of the vacuum system exhaust before venting to the atmosphere, the amount of tritium expected to be released annually from normal operations is estimated to be about $10 \mathrm{Ci}$. Experience with the Nova laser system indicates that about $0.5 \%$ of tritium input into the chamber is adsorbed on interior surfaces of the chamber, optics, and diagnostic components; this would amount to $3 \mathrm{Ci}$ release pe: $600 \mathrm{Ci}$ input. Tritium releases from the Rotating Target Neutron Source II (RTNS-II) were about $70 \mathrm{Ci} / \mathrm{y}$ fer $250,000 \mathrm{Ci}$ throughput (this scales to about $0.2 \mathrm{Ci}$ release per $600 \mathrm{Ci}$ throughput). The first Joint European Torus (IET) tritium experiment (Huguet et al., 1992) indicated that approximately $4.5 \mathrm{Ci}$ were released through the stack and possibly another $7.5 \mathrm{Ci}$ were held up in tokamak components following $977 \mathrm{Ci}$ injection into the tokamak (which scales to 3 to $7 \mathrm{Ci}$ release per $600 \mathrm{Ci}$ input ). Experience with RTNS-II, Nova, and JET suggests that tritium emissions from the tritium scrubber system would be less than $0.01 \mathrm{Ci} / \mathrm{y}$. Tritium releases from NIF would therefore resuit from desorption of tritium (primarily during chamber cleanup and maintenance) from contaminated materials.

The current exposure rate limit for individual members of the public from all sources is $0.1 \mathrm{rem} / \mathrm{y}$ (U.S. DOE, 1990; ICRP, 1990); the airborne contribution is limited to $0.01 \mathrm{rem} / \mathrm{y}$ (U.S. EPA, 1992a). To determine compliance with the emissions standard, EPA requires that the dose to members of the public be calculated using EPA-approved computer models or procedures. In this rep w 't we use the EPA-approved computer code CAP88-PC (U.S. EPA, 1992b) for dose and risk calculations.

In the atmospheric transport calculations, we used on-site meteorological data (wind direction, wind speed, atmospheric stability, etc.) for the years 1989 through 1991. This set of data is very complete and is of higher quality than those for 
previous years (Gouveia, 1992). The average annual mixing height was assumed to be $750 \mathrm{~m}$. As an example, Table 5 gives the wind and frequency-of-weather category for 1991, based on Livermore climatology data (Lamson et al., 1992). The use of annual diffusion statistics is quite appropriate for the NIF operation, because the shots will be distributed over the entire year.

In the model we considered expected air effluents for two cases, with and without the tritium scrubber or effluent recovery system. In both cases we assumed that tritium emission from the target vessel was exhausted via a 0.15-m-diam, 27-m-high stack with an exit air velocity of $1 \mathrm{~m} / \mathrm{s}$. The rates of tritium diffusion, deposition, etc., were calculated using the local climatology (e.g., see the wind rose data given in Table 5). We further assumed an average air temperature of $15^{\circ} \mathrm{C}$ and rainfall of $34 \mathrm{~cm} / \mathrm{y}$. The terrain was assumed to be flat. This oversimplified assumption tends to give conservative dose estimates; see Sec. VI for more detailed discussion of our code validation studies. Table 6 gives the food chain consumption values used in the code for the ingestion pathway dose contribution. The terrestrial food chain pathway dose was calculated using the methods specified in NRC Regulatory Guide 1.109 .

The baseline population density within an $80-\mathrm{km}$ radius of LLNL is based on the 1990 census report (Educational Data Services, 1991). For calculation, the population within the $80-\mathrm{km}$ area was distributed into regions formed by concentric circles and radial lines at $22.5^{\circ}$ intervals. Population projections in these regions were conservatively derived from 1970-92 growth rate statistics (Table 7) (State of California, 1990, 1991, 1992). The higher growth rate was used in segments where counties overlapped. The population increase within the 16-km-radius area, however, was based on the growth rates of Livermore and Pleasanton. Table 8 shows the projected population distribution within this area for the year 2000 (first year of NIF operation). The 1990 baseline population of 6.38 million is projected to increase to 7.56 million by the year 2000 . This value was used for assessing the potential individual and public exposures and risks from routine and design-basis-accident releases.

Table 9 gives the calculated annual dose equivalents for a maximally exposed individual, and for the population collectively, within an $80-\mathrm{km}$ radius area of LLNL. The tissue weighting factors used by EPA are based on ICRP 30 .
Table 10 gives the corresponding projected health risks. In obtaining the values in Table 10, the EPA dose-to-risk conversion factor of $4 \times 10^{-4}$ fatal cancers/rem for the exposed population was replaced with the more conservative value of $5 x$ $10^{-4}$ fatal cancers/rem recommended by ICRP (ICRP, 1991); this latter value is based on the best available scientific judgment and recommendations made by the National Research Council (NRC, 1990).

The exposure risks were calculated for two cases: one without the tritium recovery system, which can result in $600 \mathrm{Ci} / \mathrm{y}$ release, and one with the system, for which the expected release (primarily from cleanup and maintenance operations) is about $10 \mathrm{Ci} / \mathrm{y}$. The maximum calculated dose rates to a member of the public for releases of 10 and $600 \mathrm{Ci} / \mathrm{y}$ are $9.2 \times 10^{-7}$ and $5.5 \times 10^{-5}$ $\mathrm{rem} / \mathrm{y}$, respectively (see Table 9 ). The year- 2000 collective population dose rate without the tritium recovery system would be 7.7 person$\mathrm{rem} / \mathrm{y}$ (corresponding to an average of $10^{-6} \mathrm{rem} / \mathrm{y}$ per person, or about $0.0003 \%$ of the average natural background exposure rate). With the tritium recovery system, the population dose rate drops to 0.13 person-rem/y. In both cases, the postulated added exposure rates and the corresponding health risks are insignificant in relation to the natural radiation exposure rates $\left(2.3 \times 10^{6}\right.$ person-rem $/ y$ ) or the $16.4 \%$ background lifetime fatal cancer rate (National Academy of Sciences, 1980).

\section{B. Environmental Monitoring for Air Emissions}

Without any measures to reduce air emissions, the maximum calculated dose rate to members of the public is less than $0.0001 \mathrm{rem} / \mathrm{y}$. Since the resulting dose rate from emissions is below the EPA threshold (40 CFR 61), the NIF would be exempt from the requirement that emissions be continuously monitored. Nevertheless, the concentration of tritium in air and the total emitted through the NIF stack would be sampled on a real-time basis with ionization chambers and passively with silica gel columns. Similarly, the maximum projected concentrations for a $600 \mathrm{Ci} / \mathrm{y}$ release of tritiated water vapor (total annual input) in the Livermore Valley, based on Fig. 1, would be significantly less than 
Table 5. 1991 wind speeds and stability parameters used in the CAP88 model, based on 10-m LLNL MET tower data (Lamson et al., 1992).

Arithmetic average wind speed $(\mathrm{m} / \mathrm{s})$

\begin{tabular}{lccccccc} 
& \multicolumn{7}{c}{ Pasquill stability class } \\
\cline { 2 - 8 } Wind towards & $\mathrm{A}$ & $\mathrm{B}$ & $\mathrm{C}$ & $\mathrm{D}$ & $\mathrm{E}$ & $\mathrm{F}$ & $\mathrm{G}$ \\
\hline N & 0.855 & 1.167 & 1.844 & 1.589 & 1.429 & 0.875 & 0.813 \\
NNW & 1.167 & 1.650 & 2.625 & 1.724 & 0.948 & 0.857 & 0.692 \\
NW & 0.809 & 1.275 & 3.820 & 0.759 & 0.674 & 0.721 & 0.715 \\
WNW & 0.878 & 0.700 & 1.000 & 0.578 & 0.625 & 0.635 & 0.665 \\
W & 1.358 & 0.967 & 1.200 & 0.600 & 0.631 & 0.649 & 0.677 \\
WSW & 1.409 & 2.014 & 3.300 & 0.672 & 0.831 & 0.984 & 0.765 \\
SW & 1.747 & 2.495 & 3.344 & 3.229 & 1.545 & 1.067 & 0.781 \\
SSW & 1.487 & 2.687 & 3.517 & 3.950 & 1.144 & 1.006 & 0.754 \\
S & 1.383 & 2.546 & 4.377 & 6.420 & 1.180 & 1.135 & 0.793 \\
SSE & 1.267 & 2.060 & 3.716 & 4.200 & 1.289 & 1.433 & 0.768 \\
SE & 1.143 & 1.806 & 2.400 & 1.229 & 0.843 & 0.742 & 0.936 \\
ESE & 1.504 & 2.004 & 3.240 & 2.922 & 1.550 & 0.900 & 0.722 \\
E & 1.629 & 2.733 & 3.897 & 4.055 & 1.662 & 0.923 & 0.982 \\
ENE & 1.756 & 2.557 & 3.857 & 3.632 & 1.594 & 1.071 & 0.842 \\
NE & 1.292 & 2.236 & 3.626 & 3.977 & 1.923 & 0.952 & 0.832 \\
NNE & 1.235 & 1.163 & 2.208 & 3.276 & 2.214 & 0.979 & 0.862
\end{tabular}

Frequency of stability class

\begin{tabular}{lccccccc}
\hline & \multicolumn{7}{c}{ Pasquill stability class } \\
\cline { 2 - 8 } Wind towards & A & B & C & D & E & F & G \\
\hline N & 0.0242 & 0.0132 & 0.0198 & 0.3473 & 0.3516 & 0.0791 & 0.1648 \\
NNW & 0.0366 & 0.0081 & 0.0163 & 0.2358 & 0.2439 & 0.0935 & 0.3659 \\
NW & 0.0391 & 0.0142 & 0.0178 & 0.1922 & 0.1779 & 0.1673 & 0.3915 \\
WNW & 0.0299 & 0.0066 & 0.0000 & 0.1794 & 0.2027 & 0.1528 & 0.4286 \\
W & 0.0686 & 0.0108 & 0.0072 & 0.0578 & 0.2130 & 0.1625 & 0.4801 \\
WSW & 0.1406 & 0.0437 & 0.0063 & 0.0781 & 0.1531 & 0.1813 & 0.3969 \\
SW & 0.0827 & 0.0968 & 0.2025 & 0.2623 & 0.1408 & 0.0687 & 0.1461 \\
SSW & 0.0944 & 0.0969 & 0.2179 & 0.3317 & 0.0605 & 0.0412 & 0.1574 \\
S & 0.1688 & 0.0997 & 0.1790 & 0.3529 & 0.0512 & 0.0435 & 0.1049 \\
SSE & 0.2707 & 0.1105 & 0.1768 & 0.1215 & 0.0497 & 0.0663 & 0.2044 \\
SE & 0.4422 & 0.1156 & 0.0748 & 0.0476 & 0.0476 & 0.0816 & 0.1905 \\
ESE & 0.2836 & 0.6873 & 0.1564 & 0.2145 & 0.0727 & 0.0400 & 0.1455 \\
E & 0.1281 & 0.0974 & 0.2297 & 0.4757 & 0.0290 & 0.0111 & 0.0290 \\
ENE & 0.1451 & 0.1313 & 0.1953 & 0.4319 & 0.0429 & 0.0113 & 0.0421 \\
NE & 0.0415 & 0.0311 & 0.1030 & 0.6929 & 0.0768 & 0.0159 & 0.0387 \\
NNE & 0.0190 & 0.0089 & 0.0280 & 0.5056 & 0.3389 & 0.0313 & 0.0682 \\
Total & 0.0993 & 0.0645 & 0.1241 & 0.3978 & 0.1280 & 0.0513 & 0.1350 \\
\hline
\end{tabular}


Table 6. Agricultural data used in calculating the ingestion dose contribution from the food pathway.

\begin{tabular}{lccc}
\hline & Vegetables & Milk & Meat \\
\hline Fraction home produce & 0.076 & 0.000 & 0.008 \\
Fraction from assessment area & 0.924 & 1.000 & 0.992 \\
Fraction imported & 0.000 & 0.000 & 0.000 \\
\hline
\end{tabular}

\begin{tabular}{lr}
\hline Beef cattle density (number $/ \mathrm{km}^{2}$ ) & $8.81 \mathrm{E}-02$ \\
Milk cattle density (number $/ \mathrm{km}^{2}$ ) & $2.85 \mathrm{E}-02$ \\
$\begin{array}{l}\text { Land fraction cultivated } \\
\text { for vegetable crops }\end{array}$ & $1.18 \mathrm{E}-02$ \\
\hline
\end{tabular}

Table 7. Population growth in Alameda and neighboring counties from 1970 to 1992.

\begin{tabular}{|c|c|c|c|c|c|c|}
\hline County & Pop., 1980 & Pop.,1990 & $\begin{array}{c}\text { Growth/y, } \\
1980-92\end{array}$ & Pop.,1970 & $\begin{array}{l}\% \text { gain, } \\
1970-92\end{array}$ & $\begin{array}{c}\text { Growth/y, } \\
1970-92\end{array}$ \\
\hline Alameda $\mathbf{a}^{\mathbf{a}}$ & $1,109,500$ & $1,313,300$ & 0.0142 & $1,073,000$ & 22.40 & 0.0092 \\
\hline Contra Costa & 658,500 & 836,900 & 0.0202 & 557,500 & 50.12 & 0.0186 \\
\hline San Joaquin & 350,200 & 502,000 & 0.0305 & 292,100 & 71.86 & 0.0249 \\
\hline San Francisco & 680,500 & 728,700 & 0.0057 & 713,200 & 2.17 & 0.0010 \\
\hline Santa Clara & $1,300,200$ & $1,531,800$ & 0.0138 & $1,072,600$ & 42.81 & 0.0163 \\
\hline Stanislaus & 267,700 & 393,400 & 0.0326 & 195,800 & 100.92 & 0.0322 \\
\hline Marin & 222,700 & 237,000 & 0.0052 & 207,000 & 14.49 & 0.0062 \\
\hline San Mateo & 588,100 & 670,100 & 0.0109 & 557,100 & 20.28 & 0.0084 \\
\hline Solano & 237,200 & 364,700 & 0.0365 & 105,000 & 247.33 & 0.0582 \\
\hline Subtotal & $5,414,600$ & $6,577,900$ & 0.0164 & $4,773,300$ & 37.81 & 0.0147 \\
\hline City & 1992 & 1980 & Growth/yb & & & \\
\hline Livermore & 59,400 & 48,349 & 0.0173 & & & \\
\hline Pleasanton & 52,600 & 35,160 & 0.0341 & & & \\
\hline
\end{tabular}

a Includes Livermore and Pleasanton population data.

b Used for projecting population within 10 miles from LLNL. Year-2000 population projections in various regions were based on the growth rates for the relevant counties. The more conservative growth rate was used where counties overlapped. 
Table 8. Population distribution projected for the year 2000. The distance intervals are from LLNL to the boundaries of regions formed by $22.5 \mathrm{deg}$ radial lines and concentric circles.

\begin{tabular}{|c|c|c|c|c|c|c|c|c|c|c|c|}
\hline \multirow[b]{2}{*}{ Direction } & \multicolumn{10}{|c|}{ Distance interval (km) } & \multirow[b]{2}{*}{$0-80$} \\
\hline & $0-1.6$ & $1.6-3.2$ & $3.2-4.8$ & $4.8-6.4$ & $6.4-8$ & $8-16$ & $16-32$ & $32-48$ & $48-64$ & 64-80 & \\
\hline $\mathbf{N}$ & 12 & 112 & o & $\mathbf{0}$ & 265 & 0 & 14,281 & 33,871 & 6,989 & 3,120 & 58,650 \\
\hline NNW & 12 & 1 & 2,308 & 0 & 0 & 67 & 2,063 & 147,762 & 2,136 & 239,967 & 394,316 \\
\hline NW & 12 & 69 & 6,220 & 1,494 & 0 & 1,364 & 17,657 & 305,217 & 168,268 & 134,699 & 635,000 \\
\hline WNW & 47 & 1,227 & 31 & 17 & 0 & 213 & 85,681 & 265,833 & 556,541 & 158,971 & $1,068,561$ \\
\hline $\mathbf{W}$ & 989 & 3,176 & 4,727 & 6,868 & 11,951 & 34,541 & 94,038 & 351,608 & 486,247 & 577,365 & $1,571,510$ \\
\hline WSW & 551 & 7 & 3,448 & 4,906 & 11,192 & 20,078 & 137,086 & 148,218 & 352,663 & 21,969 & 700,118 \\
\hline SW & 119 & 202 & 5 & 114 & 14 & 10 & 98,649 & 337,746 & 151,401 & 4,477 & 592,737 \\
\hline SSW & 499 & 57 & 0 & 0 & 0 & 9 & 22,999 & 694,530 & 379,753 & 65,000 & $1,162,847$ \\
\hline $\mathbf{S}$ & 552 & 0 & $\mathbf{0}$ & $\mathbf{0}$ & 0 & 86 & o & 55,081 & 73,644 & 68,482 & 197,845 \\
\hline SSE & 151 & 155 & $\mathbf{0}$ & 0 & 0 & $\mathbf{0}$ & 282 & 6 & 71 & 3,080 & 3,745 \\
\hline SE & 261 & 0 & 0 & 0 & 0 & 0 & 281 & 18 & 80 & 13,536 & 14,176 \\
\hline ESE & 75 & $\mathbf{0}$ & 0 & 382 & 0 & 0 & 830 & 3,863 & 19,362 & 70,554 & 95,066 \\
\hline E & 151 & 0 & 0 & $\mathbf{0}$ & $\mathbf{0}$ & 137 & 12,100 & 10,908 & 210,190 & 193,145 & 426,631 \\
\hline ENE & 24 & 0 & 0 & 0 & 49 & 0 & 40,966 & 80,987 & 13,904 & 5,469 & 141,399 \\
\hline NE & 0 & $\mathbf{0}$ & 0 & $\mathbf{0}$ & 4 & 57 & 727 & 152,365 & 282,384 & 16,362 & 451,899 \\
\hline NNE & 24 & $\mathbf{0}$ & $\mathbf{0}$ & $\mathbf{0}$ & 0 & $\mathbf{0}$ & 8,752 & 1,568 & 8,347 & 28,766 & 47,457 \\
\hline$\overline{\text { Total }}$ & $\overline{3,479}$ & $\overline{5,006}$ & $\overline{16,739}$ & $\overline{13,781}$ & $\overline{23,475}$ & $\overline{56,562}$ & $\overline{536,392}$ & $\overline{2,589,581}$ & $\overline{2,711,980}$ & $\overline{1,604,962}$ & $\overline{7,561,957}$ \\
\hline
\end{tabular}


Table 9. Calculated dose equivalents for the maximally exposed individual and for the collective year-2000 population within an $80-\mathrm{km}$ radius area of LLNL for $10 \mathrm{Ci} / \mathrm{y}$ (unless noted otherwise) tritium emission. The maximally exposed individual is assumed to reside $800 \mathrm{~m}$ north northeast of the National Ignition Facility.

\begin{tabular}{lcc}
\hline Organ & $\begin{array}{l}\text { Maximum } \\
\text { individual } \\
\text { (rem/y) }\end{array}$ & $\begin{array}{l}\text { Collective } \\
\text { population } \\
\text { (person-rem/y) }\end{array}$ \\
\hline Gonads & $9.03 \mathrm{E}-07$ & $1.22 \mathrm{E}-01$ \\
Breast & $9.03 \mathrm{E}-07$ & $1.22 \mathrm{E}-01$ \\
Red bone marrow & $8.96 \mathrm{E}-07$ & $1.22 \mathrm{E}-01$ \\
Lungs & $9.03 \mathrm{E}-07$ & $1.23 \mathrm{E}-01$ \\
Thyroid & $8.96 \mathrm{E}-07$ & $1.22 \mathrm{E}-01$ \\
Bone surfaces & $7.11 \mathrm{E}-07$ & $9.65 \mathrm{E}-02$ \\
Remainder & $9.75 \mathrm{E}-07$ & $1.43 \mathrm{E}-01$ \\
Effective dose & $9.17 \mathrm{E}-07$ & $1.28 \mathrm{E}-01$ \\
Effective dose $(600 \mathrm{Ci})$ & $5.50 \mathrm{E}-05$ & $7.68 \mathrm{E}+00$
\end{tabular}

Pathway contributions to the effective dose equivalents

\begin{tabular}{lll} 
Pathway & $\begin{array}{l}\text { Maximum } \\
\text { individual } \\
\text { (rem/y) }\end{array}$ & $\begin{array}{l}\text { Collective } \\
\text { population } \\
\text { (person-rem/y) }\end{array}$ \\
\hline Ingestion & $8.04 \mathrm{E}-08$ & $6.08 \mathrm{E}-02$ \\
Inhalation & $8.37 \mathrm{E}-07$ & $6.69 \mathrm{E}-02$ \\
Air immersion & $0.00 \mathrm{E}+00$ & $0.00 \mathrm{E}+00$ \\
Ground surface & $0.00 \mathrm{E}+00$ & $0.00 \mathrm{E}+00$ \\
Internal & $9.18 \mathrm{E}-07$ & $1.28 \mathrm{E}-01$ \\
External & $0.00 \mathrm{E}+00$ & $0.00 \mathrm{E}+00$ \\
Total & $9.18 \mathrm{E}-07$ & $1.28 \mathrm{E}-01$ \\
\hline
\end{tabular}


Table 10. Projected health risks for maximally exposed individual and for the year-2000 area population within an $80-\mathrm{km}$ radius area of $L L N L$ for $10 \mathrm{Ci} / \mathrm{y}$ tritium emission.

\begin{tabular}{lcc}
\hline Cancer type & $\begin{array}{c}\text { Maximally exposed } \\
\text { individual total } \\
\text { lifetime fatal } \\
\text { cancer risk }^{\mathrm{a}}\end{array}$ & $\begin{array}{c}\text { Total collective } \\
\text { population fatal } \\
\text { cancer risk } \\
\text { (deaths/y) }^{\mathrm{a}}\end{array}$ \\
\hline Leukemia & $3.55 \mathrm{E}-09$ & $6.80 \mathrm{E}-06$ \\
Bone & $1.58 \mathrm{E}-10$ & $3.01 \mathrm{E}-07$ \\
Thyroid & $5.09 \mathrm{E}-10$ & $9.78 \mathrm{E}-07$ \\
Breast & $4.43 \mathrm{E}-09$ & $8.46 \mathrm{E}-06$ \\
Lung & $5.60 \mathrm{E}-09$ & $1.08 \mathrm{E}-05$ \\
Stomach & $3.76 \mathrm{E}-09$ & $8.00 \mathrm{E}-06$ \\
Bowel & $2.01 \mathrm{E}-09$ & $4.34 \mathrm{E}-06$ \\
Liver & $3.93 \mathrm{E}-09$ & $7.54 \mathrm{E}-06$ \\
Pancreas & $2.68 \mathrm{E}-09$ & $5.13 \mathrm{E}-06$ \\
Urinary & $1.46 \mathrm{E}-09$ & $2.80 \mathrm{E}-06$ \\
Other & $3.26 \mathrm{E}-09$ & $6.26 \mathrm{E}-06$ \\
Total & $3.14 \mathrm{E}-08$ & $6.14 \mathrm{E}-05^{\mathrm{b}}$ \\
\hline
\end{tabular}

Based on the ICRP 60 population risk factors.

${ }^{b}$ Population average equals $8.1 \times 10^{-12} \mathrm{fatal}$ cancers/y for a release rate of $10 \mathrm{Ci} / \mathrm{y}$.

the environmental compliance value of $1.5 \times 10^{3} \mathrm{pCi} / \mathrm{m}^{3}$ (U.S. EPA, 1992c).

With the scrubber system in operation, the expected tritium concentrations (Fig. 1) would be well below the current detection limit of $2 \mathrm{pCi} / \mathrm{m}^{3}$ for tritium (Guthrie, 1992). Since the code overpredicts the concentrations on average by a factor of 1.1 to 3.2, the actual concentrations in the Livermore Valley air are expected to be well below $1 \mathrm{pCi} / \mathrm{m}^{3}$.

The expected radioactivity in air, vegetation, groundwater, etc., in the Livermore Valley and at the site boundary will have negligible added impact on the environment and human health, so LLNL's existing environmental monitoring program would provide more than adequate coverage for NIF operations.

\section{Air Activation}

Air in the NIF target room between the target chamber shield and the concrete walls is subject to neutron activation. In the neutron transport calculations, the air interface was modeled radially from 4 to $14 \mathrm{~m}$ with a 0.6 -m-thick concrete shell on the outside to account for room scattering. It was assumed that $13 \%$ of the DT neutrons produced in the target chamber emerge into the room air through the beam and diagnostics ports. The air composition was assumed to be that of dry air (78.4 at.\% N, 21.12 at.\% O, and 0.48 at.\% Ar). The neutron transport calculations were performed using the TART code and its associated neutron cross section libraries (Plechaty and Kimlinger, 1976). All results were normalized to a baseline annual fusion yield of $1.4 \times 10^{2 \mathrm{C}}$ JT neutrons.

Table 11 lists important radionuclides produced in the target room air. Release of activated gases is assumed to occur at a rate of $1 \%$ of room volume per minute through the building stack.

The stack emissions can be calculated from the differential equations describing the change 


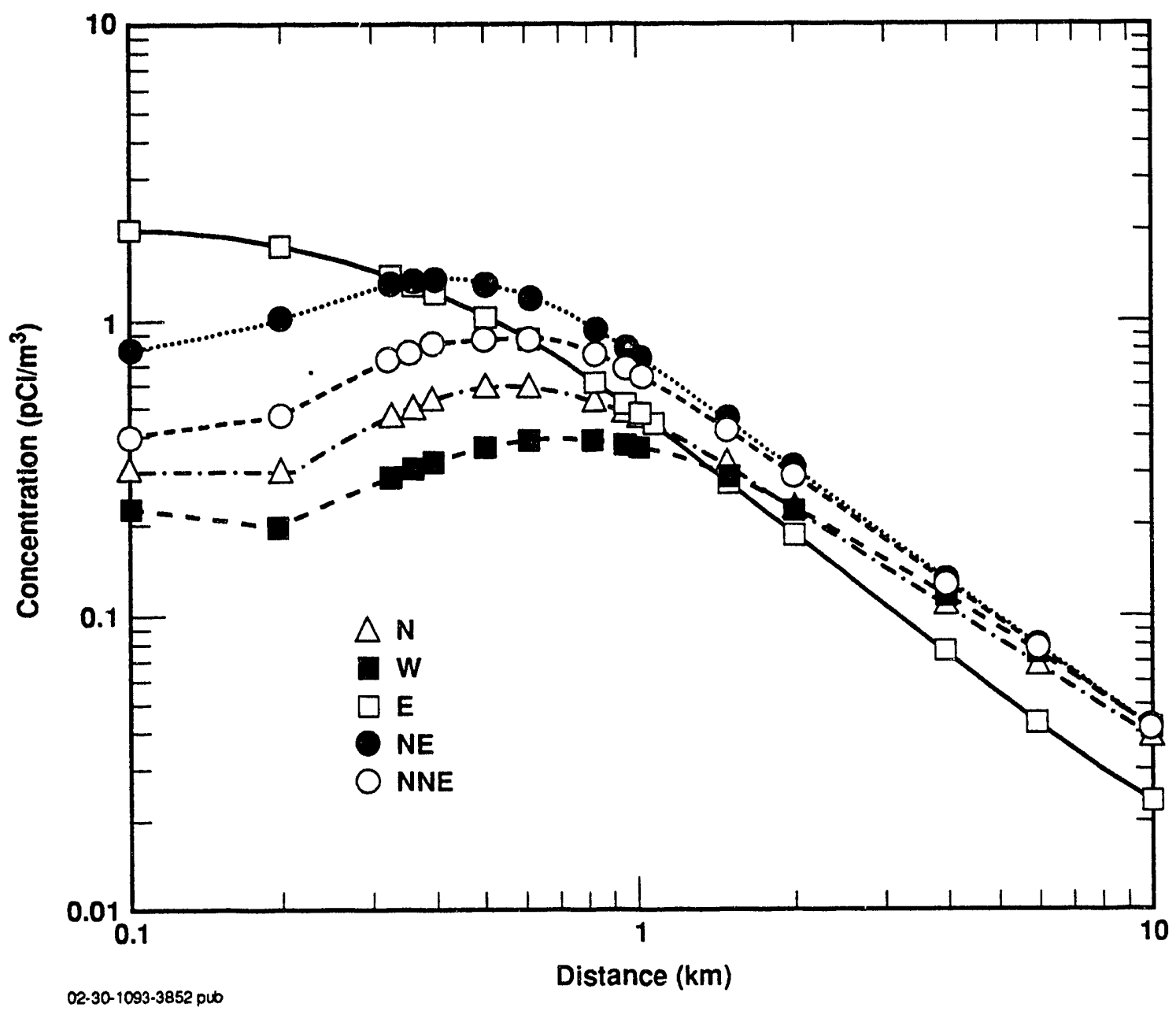

Figure 1. Projected tritium concentrations vs distance and direction in Livermore Valley air for a 10-Ci/y release through the NIF stack. LLNL meteorological data used in the calculations were averages for the years 1989 through 1991.

Table 11. Neutron-induced radioactivity produced in target room air, based on $1.4 \times 10^{20}$ DT neutrons per year with $13 \%$ transmission through the target chamber openings.

\begin{tabular}{llcc}
\hline Nuclide & Half-life & $\begin{array}{c}\text { Production } \\
\text { (Ci/y) }\end{array}$ & $\begin{array}{c}\text { Stack } \\
\text { emissions } \\
(\mathrm{Ci} / \mathrm{y})\end{array}$ \\
\hline${ }^{13} \mathrm{~N}$ & $9.99 \mathrm{~min}$ & 146 & 18.5 \\
${ }^{16} \mathrm{~N}$ & $7.13 \mathrm{sec}$ & 20450 & 35.0 \\
${ }^{37} \mathrm{~S}$ & $5.06 \mathrm{~min}$ & 4.2 & 0.29 \\
${ }^{40} \mathrm{Cl}$ & $1.42 \mathrm{~min}$ & 15.3 & 0.31 \\
${ }^{41} \mathrm{Ar}$ & $1.83 \mathrm{hr}$ & 5.36 & 3.28 \\
${ }^{14} \mathrm{C}$ & $5730 \mathrm{y}$ & $9.27 \mathrm{E}-5$ & $9.27 \mathrm{E}-5$ \\
${ }^{3} \mathrm{H}$ & $12.33 \mathrm{y}$ & $1.12 \mathrm{E}-3$ & $1.12 \mathrm{E}-3$ \\
\hline
\end{tabular}

in radioactivity in the target room following a fusion shot:

$$
\begin{aligned}
& \frac{d A}{d t}=-C_{\mathrm{e}} v_{\mathrm{e}}-\lambda A \\
& \frac{d C}{d t}=-C_{\mathrm{e}} \frac{v_{\mathrm{e}}}{v_{\mathrm{r}}}-C \lambda \\
& C=C_{0} e^{-(\alpha+\lambda) t} \\
& R=\int_{0}^{\infty} C_{0} e^{-(\alpha+\lambda) t} v_{\mathrm{e}} d t=\frac{A_{0} \alpha}{\alpha+\lambda}
\end{aligned}
$$

where $A=$ activity in the room at time $t ; C_{\mathrm{e}}=$ effluent discharge concentration; $v_{\mathrm{e}}=$ effluent volume flow rate; $\lambda=$ radioactive-decay constant, $v_{\mathrm{r}}=$ room volume, $C=$ room concentration at time $t ; C_{0}=A_{0} / v_{\mathrm{r}}$ and $R=$ amount discharged following a fusion shot from $t=0$ to $t=\infty$. Table 11 
shows stack emissions based on these equations, with $v_{\mathrm{e}} / v_{\mathrm{r}} \equiv \alpha=0.01 \mathrm{~min}^{-1}$.

In dose and risk calculations, we assumed the same values for food consumption, population density, meteorology, and other parameters as those used in Sec. II.A for tritium dose and risk calculations. Table 12 gives the calculated annual a'oses from activated-air emissions. The maximum projected individual and population dose rates are $6.6 \times 10^{-6} \mathrm{rem} / \mathrm{y}$ and $1.2 \times 10^{-2}$ person$\mathrm{rem} / \mathrm{y}$, respectively. This is insignificant in relation to the emission standards and the natural background radiation intensity. The added health risks at these exposure rates are insignificant: the maximum individual total lifetime fatal cancer risk, weighted over 70 y of exposure, is $2.3 \times 10^{-7}$, and the total collective population risk is $6 \times 10^{-6}$ deaths per year.

Table 12. Projected year-2000 doses due to postulated activated-air emissions from the NIF. With a 2-hr holdup, the dose drops by a factor of 10 .

\begin{tabular}{lcccc}
\hline Nuclide & $\begin{array}{c}\text { Emission amount } \\
(\mathrm{Ci})^{\mathrm{a}}\end{array}$ & $\begin{array}{c}\text { Endividual } \\
(\mathrm{rem} / \mathrm{y})^{\mathrm{b}}\end{array}$ & $\begin{array}{c}\text { Population } \\
(\text { person-rem/y) }\end{array}$ & $\begin{array}{c}\text { Site boundary } \\
(\mathrm{rem} / \mathrm{y})^{\mathrm{d}}\end{array}$ \\
\hline${ }^{13} \mathrm{~N}$ & 18.5 & $4.8 \mathrm{E}-6$ & $3.8 \mathrm{E}-3$ & $3.0 \mathrm{E}-6$ \\
${ }^{16} \mathrm{~N}$ & 35.0 & $2.2 \mathrm{E}-23$ & - & $1.0 \mathrm{E}-15$ \\
${ }^{37} \mathrm{~S}$ & 0.29 & $1.5 \mathrm{E}-7$ & - & $4.2 \mathrm{E}-7$ \\
${ }^{40} \mathrm{Cl}$ & 0.31 & $1.2 \mathrm{E}-8$ & - & $2.6 \mathrm{E}-7$ \\
${ }^{41} \mathrm{Ar}$ & 3.28 & $1.6 \mathrm{E}-6$ & $8.5 \mathrm{E}-3$ & $4.3 \mathrm{E}-7$ \\
${ }^{14} \mathrm{C}$ & $9.25 \mathrm{E}-5$ & $1.4 \mathrm{E}-11$ & $2.2 \mathrm{E}-5$ & - \\
${ }^{3} \mathrm{H}$ & $1.12 \mathrm{E}-3$ & $9.6 \mathrm{E}-11$ & $1.2 \mathrm{E}-5$ & - \\
Total & & $6.6 \mathrm{E}-6$ & $1.2 \mathrm{E}-2$ & $4.1 \mathrm{E}-6$ \\
\hline
\end{tabular}

a The air activated species are released at a rate of $1 \%$ of the target room volume per minute. It is assumed that $13 \%$ of the primary neutrons leak into the target room air. Results were normalized to $1.4 \times 10^{20} \mathrm{DT}$ neutrons.

$b$ This dose equivalent is the maximum potential dose from all pathways to a member of the public residing at $800 \mathrm{~m}$ north northeast of LLNL Bldg. 391. The effective dose equivalents resulting from internal and external exposures have been weighted over the irradiated organs and tissues.

' The dose equivalent is for the projected population ( 7.56 million people) residing within an $80-\mathrm{km}$ radius of LLNL. The effective dose equivalents resulting from internal and external exposures have been weighted over the irradiated organs and tissues.

d The closest site boundary is $330 \mathrm{~m}$ north of Bldg. 391 . At this location, the ratio $\chi / Q$ of the atmospheric dispersion to the source term is about $1.26 \times 10^{-6} \mathrm{~s} / \mathrm{m}^{3}$, and the annual average wind speed is $1.1 \mathrm{~m} / \mathrm{s}$. 


\section{Neutron Skyshine and Direct Radiation}

\section{A. Skyshine}

"Skyshine" is radiation at the receptor location, generally on the ground, arising from collisions with air nuclei by radiation transmitted into the atmosphere through the building roof. Radiation transmitted through the building walls is considered "direct" radiation. Both skyshine and direct radiation can contribute to appreciable exposure rates around and above the NIF.

Table 13 lists the numbers of projected NIF experiments at various yields (Campbell et al., 1992); calculations are normalized to an average annual yield of $1.4 \times 10^{20}$ DT neutrons. The facility is expected to operate for 20 to 30 years.

Table 14 ives the neutron source parameters used for neutron transport calculations. The DT neutron source is defined in terms of polar and azimuthal angles that represent about $13 \%$ of the $4 \pi$ solid angle. The target room measures $30.5 \times 15.2 \mathrm{~m}$, with a height of $26 \mathrm{~m}$. The roof is $1.22-\mathrm{m}$-thick reinforced concrete, and the walls are $1.83-\mathrm{m}$-thirk reinforced concrete. Figure 2 shows the calculated skyshine dose at ground level as a function of distance from the center of the NIF target room, again for an annual yield of $1.4 \times 10^{20}$ DT neutrons. The maximum dose occurs at about $50 \mathrm{~m}$ from the center of the room. The sum of skyshine and direct exposure rates will remain less than $0.1 \mathrm{rem} / \mathrm{y}$; the value could

Table 13. Fusion yield associated with the NIF experiments.

\begin{tabular}{|c|c|c|c|}
\hline \multirow{2}{*}{$\begin{array}{c}\text { Fusion yield } \\
\text { per } \\
\text { experiment }\end{array}$} & \multirow{2}{*}{$\begin{array}{c}\begin{array}{c}\text { Number } \\
\text { of } \\
\text { experiments }\end{array} \\
\end{array}$} & \multicolumn{2}{|c|}{ Annual fusion yield } \\
\hline & & $\begin{array}{c}\text { Energy } \\
\text { (MJ) }\end{array}$ & Neutrons \\
\hline $100 \mathrm{~kJ}$ & 100 & 10 & $3.6 \mathrm{E} 18$ \\
\hline $5 \mathrm{MJ}$ & 35 & 175 & $6.2 \mathrm{E} 19$ \\
\hline $20 \mathrm{MJ}$ & 10 & 200 & 7.1E19 \\
\hline Total & 145 & 385 & 1.4E20 \\
\hline
\end{tabular}

go considerably lower, depending on cost-benefit and social factors. The shielding design philosophy will be the same as that used for RTNS-II, which allowed unlimited access outside the target cells. Depending on the final shielding configuration, access to the roof may be controlled during the DT shots to minimize personnel exposure.

\section{B. Direct Radiation}

The intensity of direct radiation outside the building was calculated with the assumption that the chamber is $0.10-\mathrm{m}$-thick $\mathrm{Al}$, surrounded by a nonflammable material that provides neutron shielding equivalent to $0.30 \mathrm{~m}$ of polyethylene, and that the walls are 1.83 -m-thick ordinary concrete. Figures 3,4 , and 5 give the transmission of neutrons and secondary gammas in these materials. Outside the building, the radiation intensity is due primarily to secondary gamma rays. Figure 2 shows the direct and skyshine contributions. With this shielding configuration, the maximum radiation intensity is significantly less than the NIF exposure criterion $(0.1 \mathrm{rem} / \mathrm{y})$ for unrestricted access around the facility. Further dose reduction can be achieved by using costbenefit analysis to optimize the shielding configuration.

Table 14. Neutron source distribution (cosines of polar angles between which neutrons are emitted) used in skyshine calculations. The azimuthal angle is from 0 to $2 \pi$.

\begin{tabular}{cc}
\hline $\cos \theta_{1}$ & $\cos \theta_{2}$ \\
\hline 0.92 & 0.943 \\
0.854 & 0.877 \\
0.627 & 0.674 \\
0.515 & 0.562 \\
-0.943 & -0.92 \\
-0.877 & -0.854 \\
-0.674 & -0.627 \\
-0.562 & -0.515 \\
\hline
\end{tabular}




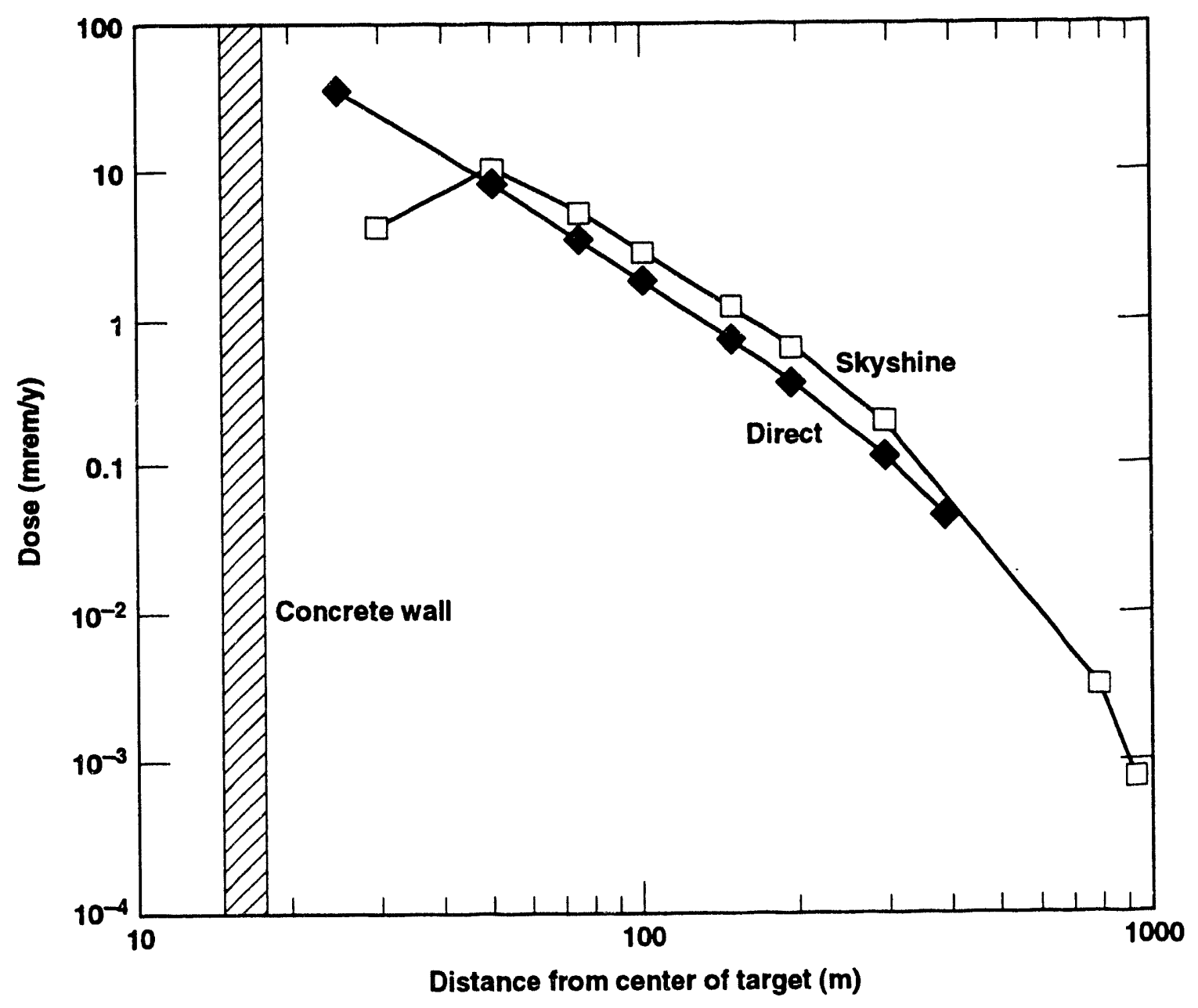

02-30-1093-3853 pub

Figure 2. Projected neutron skyshine and direct radiation intensities (maximum) outside the NIF. The skyshine contribution is from radiation transmitted through the 1.83-m-thick concrete roof. The direct contribution is from radiation transmitted through the 0.10 -m-thick Al chamber, $0.30 \mathrm{~m}$ of polyethylene, and 1.83-m-thick concrete walls. (In practice, a nonflammable material that provides neutron shielding equivalent to $0.30 \mathrm{~m}$ of polyethylene will be used; a possible example is ordinary concrite containing $2.5 \mathrm{wt} \%$ boron.) 


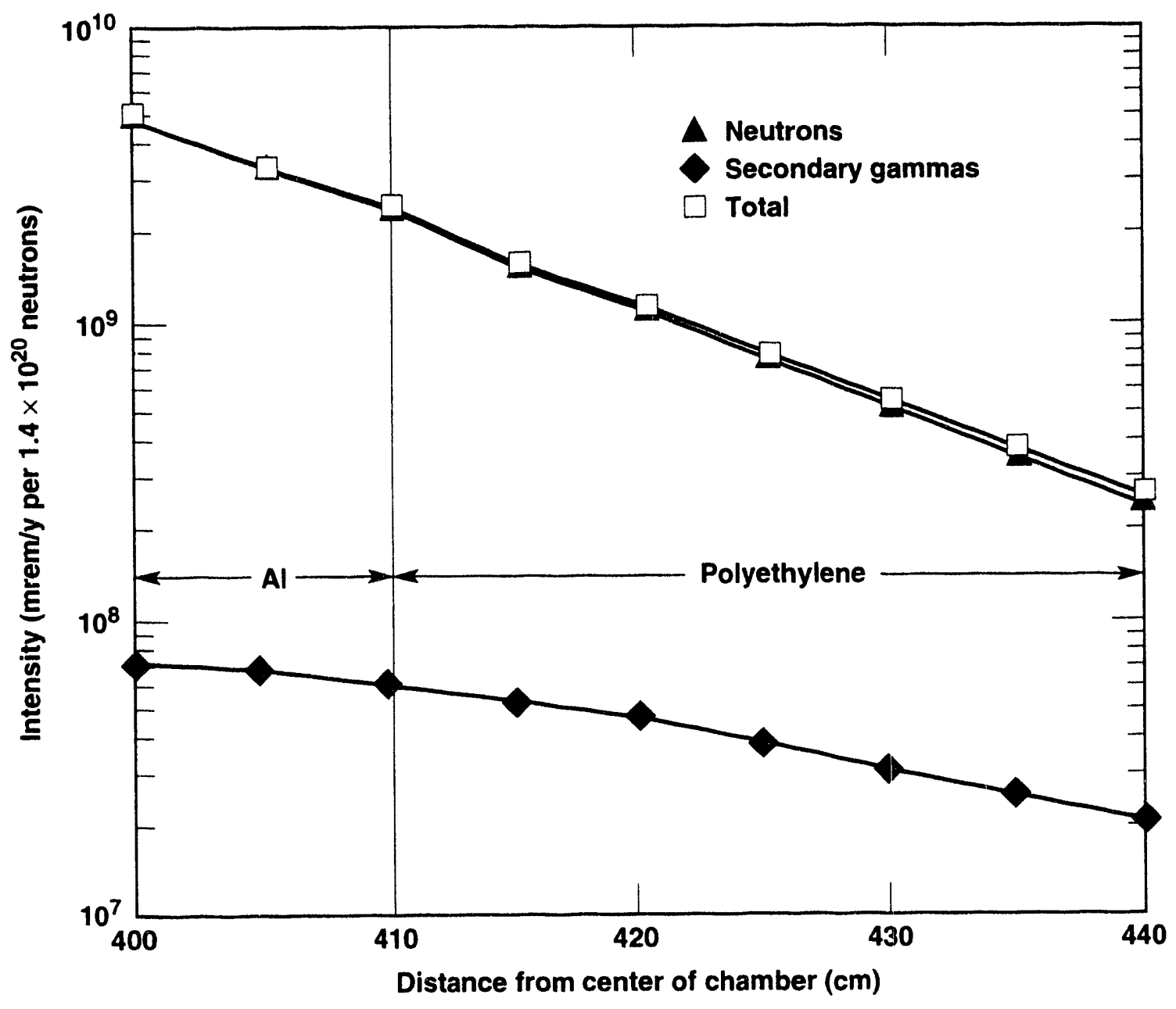

$02 \cdot 30 \cdot 1093-3854$ pub

Figure 3. Neutron and secondary gamma-ray transmission in $0.10-\mathrm{m}$-thick $\mathrm{Al}$ chamber and $0.30 \mathrm{~m}$ of polyethylene. 


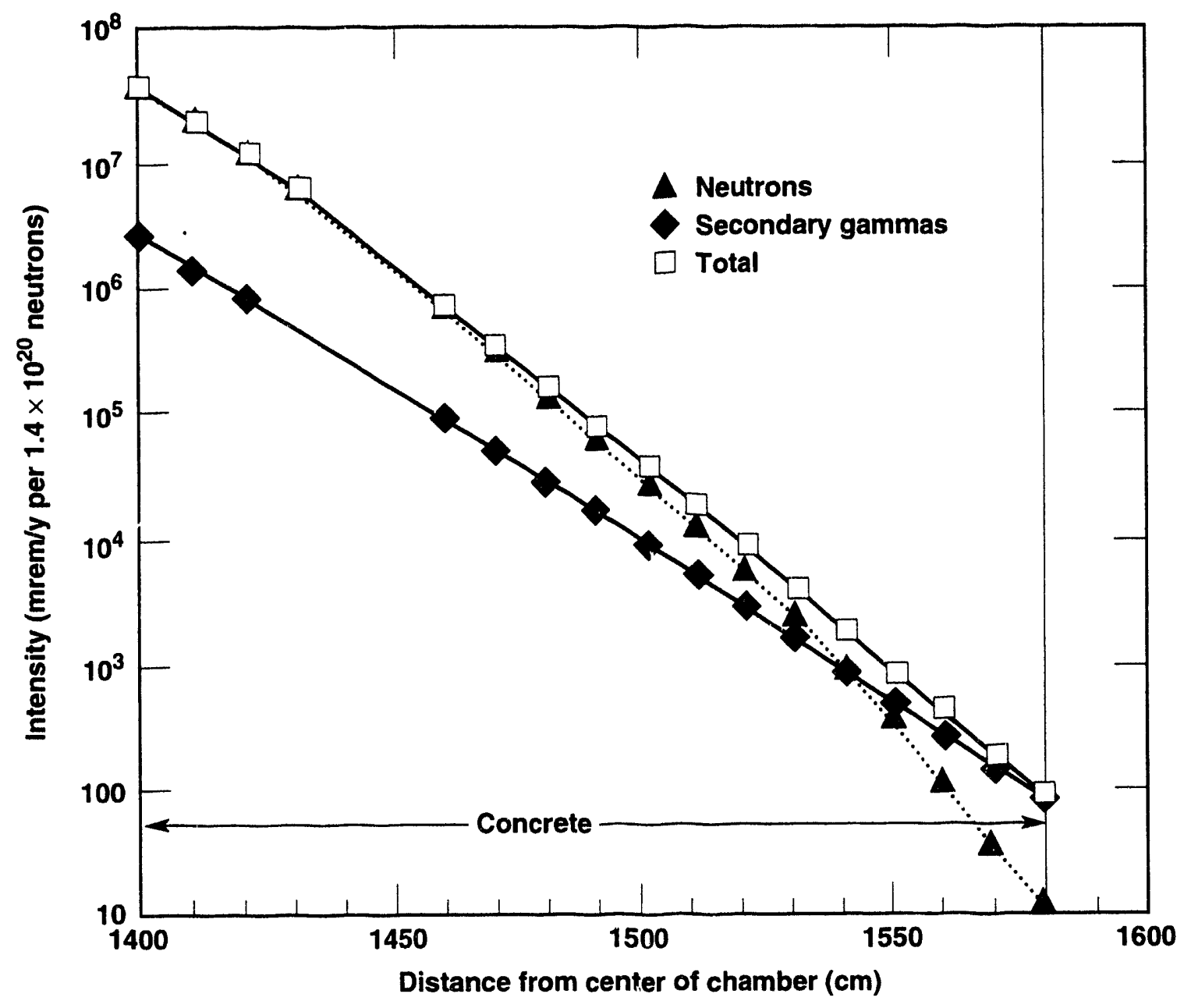

02-30-1093-3855 pub

Figure 4. Neutron and secondary gamma-ray transmission in 1.83-m-thick concrete shield after passing through the materials indicated in Fig. 3. 


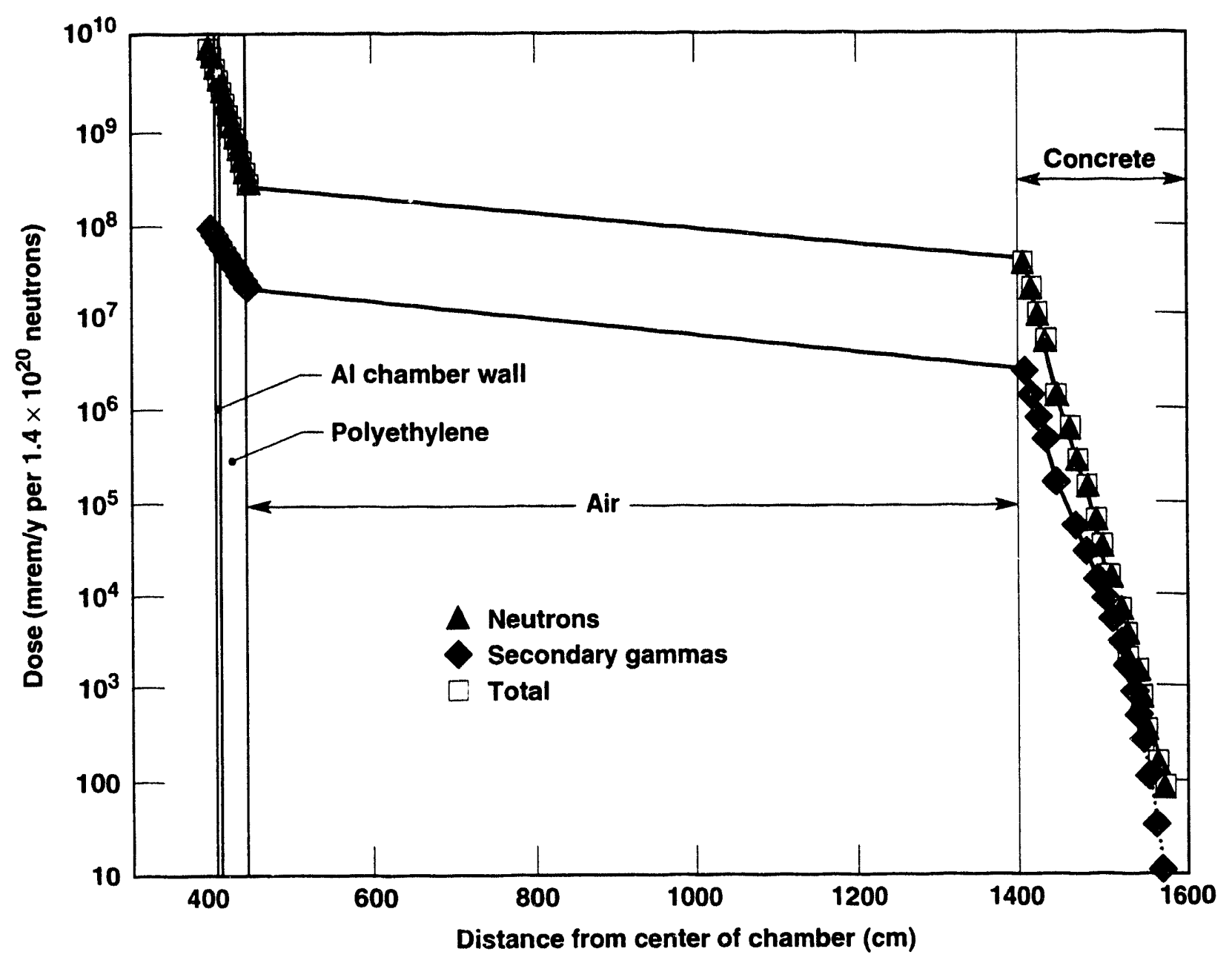

02-30-1093-3856 pub

Figure 5. Transmission of neutron and secondary radiation through 0.10 -m-thick $\mathrm{Al}$ chamber, $0.30 \mathrm{~m}$ of polyethylene, and a 1.83-m-thick concrete shield. (Contains the data of Figs. 3 and 4 on a single plot.) 
UCRL-LR-115188 


\section{Occupational Exposure Rates}

Annual prompt dos,e rates were calculated for areas inside and outside the NIF. For a 40-hour workweek, the dose cate in all areas would be less than $0.01 \mathrm{rem} / \mathrm{y}$. The dose rates in the control room and war room would be less than $0.0024 \mathrm{rem} / \mathrm{y}$ (Latkowski and Tobin, 1993). Dose rates inside the building are dominated by direct radiation. Some areas where doses are likely to be higher would be restricted during the highyield shots.

Occupational exposure would arise mainly from the residual radioactivity in various structural components of the NIF chamber, space frame, target debris, optics, and concrete. As already shown in Table 3, occupational doses will be kept at least a factor of 10 below the DOE administrative guide and the current DOE/ICRP occupational standards. Calculations show that unlimited entry to the target area can be permitted 1 day after a $100-\mathrm{kJ}$ shot, 5 days after a $5-\mathrm{MJ}$ shot, and 6 days after a 20-MJ shot (Latkowski and Tobin, 1993). Limited-duration entry could begin sooner. Occupational radiation doses would be controlled in accordance with applicable DOE orders and policies and with LLNL ALARA principles. 


\section{Decontamination and Decommissioning}

After 20 years of NIF operation, the facility might require decontamination in conjunction with decommissioning (D\&D). Since there would be less than $10 \mathrm{Ci}$ of residual tritium in the vessel, and the residual radioactivity in the structural and shielding components would be similar to that normally associated with accelerator facilities, D\&D of the NIF would present no unusual problems.

The amount of neutron-induced radioactivity on the interior surfaces of the vessel would be governed primarily by the activation of target materials that, after vaporization, are deposited on the internal surfaces of the chamber. Calculations (Latkowski and Tobin, 1993) show that after 20 years of operation, the surface dose rate in the vessel from such material would be $0.04 \mathrm{rem} / \mathrm{hr}$.
This assumes the use of a cryogenic system made of stainless steel and copper. If the cryosystem is made of aluminum, the residual radioactivities are reduced to insignificant values. The design criterion dose rate of $0.2 \mathrm{rem} / \mathrm{y}$ will be used for cleaning, dismantling, and removal of activated components.

Neutron activation calculations (Latkowski and Tobin, 1993) for the vessel, shields, concrete walls, and space frame show that the residual long-term activity would be dominated by ${ }^{54} \mathrm{Mn}$ (312-day half-life) and ${ }^{59} \mathrm{Fe}$ (45-day half-life) in the rebar in the concrete walls. Under a worstcase scenario, the residual radiation intensity at the wall surfaces would be $0.002 \mathrm{rem} / \mathrm{hr}$. This intensity would present no unusual radiological hazards for D\&D operations. 


\section{Environmental Transport of Tritium: Validation of the EPA CAP88-PC Code}

\section{A. Air Pathway}

The CAP88-PC code is a modified version of the AIRDOS-EPA program for calculating environmental transport of atmospheric emissions. The uncertainties in the predicted results for the Livermore Valley can be determined by using the high-quality, well-documented data for LLNL and SNL tritium emissions, local meteorology, environmental monitoring (air, vegetation and soil), and emission parameters.

Table 15 gives the past annual tritium emissions from LLNL and SNL; Table 16 gives the tritium stack dimensions and effluent emission velocity, which are used for plume rise (Wong, 1989; Brekke, 1992). Local meteorology data for years 1989 through 1991 (Gouveia, 1992) were used for plume dispersion calculations. EPA-recommended values were used for tritium deposition, precipitation scavenging (based on rainfall), and plume depletion.

In the source term, we used the HTO emissions, because HTO is the major contributor to the measured tritium concentrations in soil, collected water vapor, and vegetation. Tables 17 through 20 give the results of atmospheric transport calculations and the measured air
Table 16. LLNL (Bldg. 331) and Sandia (TRL) stack and emission velocity parameters used in the tritium atmospheric dispersion calculations.

\begin{tabular}{lcc}
\hline \multicolumn{1}{c}{ Parameter } & LLNL & TRL \\
\hline Stack height $(\mathrm{m})$ & 30 & 30 \\
Stack diameter $(\mathrm{m})$ & 1.18 & 1.4 \\
Gas exit velocity $(\mathrm{m} / \mathrm{s})$ & 9 & 1.5 \\
\hline
\end{tabular}

concentrations on- and off-site (Lawrence Livermore National Laboratory, 1986-1991). Figure 6 shows tritium sampling locations.

The benchmark calculations indicate that, on average, the CAP88-PC code overpredicts the tritium concentrations within a $10-\mathrm{km}$ radius by a factor of 1.1 to 3.2 . Between $10-$ and $80-\mathrm{km}$ radius, one would expect greater dispersion because of hills, mountains, ridges, ravines, changes in ground elevation (which varies from 200 to $90 \mathrm{~m}$ from east to west), and urban heating. The results predicted by the code are therefore fairly conservative.

Table 15. Tritium emissions from LLNL and SNL for the past 6 years. Emissions are divided into two categories: tritiated water vapor (HTO) and tritium gas.

\begin{tabular}{lrrrrrrrr}
\hline & \multicolumn{3}{c}{ Tritiated water (Ci) } & & \multicolumn{2}{c}{ Tritiated water plus gas (Ci) } \\
\cline { 2 - 3 } \cline { 7 - 8 } Year & Total & LLNL & SNL & & Total & LLNL & SNL \\
\hline 1986 & 1,403 & 774 & 629 & & 2,014 & 1,254 & 760 \\
1987 & 1,899 & 1,329 & 570 & & 4,578 & 2,751 & 1,827 \\
1988 & 2,688 & 1,641 & 1,047 & & 5,573 & 3,983 & 1,590 \\
1989 & 2,210 & 1,554 & 656 & & 3,786 & 2,952 & 834 \\
1990 & 944 & 700 & 244 & & 1,577 & 1,282 & 295 \\
1991 & 1,028 & 678 & 350 & & 1,573 & 1,110 & 463 \\
Total & 10,172 & 6,676 & 3,496 & & 19,101 & 13,332 & 5,769 \\
Average & 1,695 & 1,113 & 583 & & 3,184 & 2,222 & 962 \\
\hline
\end{tabular}


Table 17. Distances (in kilometers) and directions of sampling locations (Fig. 6) from LLNL and TRL stacks, and predicted and measured tritium concentrations in air in the Livermore Valley for the years 1989 to 1991.

\begin{tabular}{lllllll}
\hline $\begin{array}{c}\text { Distance } \\
(\mathbf{k m}) \text { from }\end{array}$ & XRDS & VET & ZON7 & ALTA & LCCY & FIRE \\
\hline Bldg. 331 & $2.1 \mathrm{SE}$ & $1.9 \mathrm{SW}$ & $3.7 \mathrm{NE}$ & $9.1 \mathrm{NNE}$ & $5.6 \mathrm{~W}$ & $3.1 \mathrm{~W}$ \\
TRL & $1.3 \mathrm{E}$ & $1.6 \mathrm{~W}$ & $4.4 \mathrm{NE}$ & $10.0 \mathrm{NNE}$ & $5.9 \mathrm{WNW}$ & $3.3 \mathrm{WNW}$
\end{tabular}

Tritium concentrations in air $\left(\mathrm{Ci} / \mathrm{m}^{3}\right)$

\begin{tabular}{|c|c|c|c|c|c|c|}
\hline & XRDS & VFT & ZON7 & ALTA & LCCY & FIRE \\
\hline \multicolumn{7}{|c|}{ 1989, calculated } \\
\hline TRL & $1.96 \mathrm{E}-11$ & $1.89 \mathrm{E}-11$ & 8.11E-12 & 3.33E-12 & $6.45 \mathrm{E}-12$ & $1.16 \mathrm{E}-11$ \\
\hline LLNL & $3.38 \mathrm{E}-12$ & $2.28 \mathrm{E}-11$ & $1.85 \mathrm{E}-11$ & $6.96 \mathrm{E}-12$ & $9.41 \mathrm{E}-12$ & $1.42 \mathrm{E}-11$ \\
\hline Total & 2.29E-11 & 4.18E-11 & $2.66 \mathrm{E}-11$ & 1.03E-11 & 1.59E-11 & $2.58 \mathrm{E}-11$ \\
\hline \multicolumn{7}{|c|}{1989 , measured } \\
\hline & 8.00E-12 & $1.40 \mathrm{E}-11$ & $1.40 \mathrm{E}-11$ & $5.00 \mathrm{E}-12$ & 4.00E-12 & $7.00 \mathrm{E}-12$ \\
\hline \multicolumn{7}{|c|}{1990 , calculated } \\
\hline TRL & $7.74 \mathrm{E}-12$ & $3.48 \mathrm{E}-12$ & 2.17E-12 & $6.73 E-13$ & 8.51E-13 & $1.62 \mathrm{E}-12$ \\
\hline LLNL & $3.33 \mathrm{E}-12$ & $7.55 \mathrm{E}-12$ & 7.99E-12 & $1.91 \mathrm{E}-12$ & $2.00 \mathrm{E}-12$ & $3.77 \mathrm{E}-12$ \\
\hline Total & $1.1 \mathrm{E}-11$ & 1.1E-11 & $1.0 \mathrm{E}-11$ & $2.6 \mathrm{E}-12$ & $2.8 \mathrm{E}-12$ & $5.4 \mathrm{E}-12$ \\
\hline \multicolumn{7}{|c|}{1990, measured } \\
\hline & 4.70E-12 & $7.10 \mathrm{E}-12$ & 8.70E-12 & $5.50 \mathrm{E}-12$ & $2.90 \mathrm{E}-12$ & $3.80 \mathrm{E}-12$ \\
\hline \multicolumn{7}{|c|}{ 1991, calculated } \\
\hline TRL & $1.03 E-11$ & 4.72E-12 & 3.33E-12 & $1.27 \mathrm{E}-12$ & 1.72E-12 & $3.28 \mathrm{E}-12$ \\
\hline LLNL & 1.39E-12 & 7.37E-12 & 7.31E-12 & $2.36 \mathrm{E}-12$ & $1.76 \mathrm{E}-12$ & $2.88 \mathrm{E}-12$ \\
\hline \multicolumn{7}{|c|}{1991 , measured } \\
\hline & $3.40 E-12$ & 8.00E-12 & $5.60 \mathrm{E}-12$ & $3.50 \mathrm{E}-12$ & $3.30 \mathrm{E}-12$ & $4.20 \mathrm{E}-12$ \\
\hline
\end{tabular}

Table 18. Predicted-to-measured tritium concentration ratio for the off-site tritium sampling stations.

\begin{tabular}{lcccccc}
\hline Year & XRDS & VET & ZON7 & ALTA & LCCY & FIRE \\
\hline 1989 & 2.87 & 2.98 & 1.90 & 2.06 & 3.96 & 3.69 \\
1990 & 2.35 & 1.55 & 1.17 & 0.47 & 0.98 & 1.42 \\
1991 & 3.43 & 1.51 & 1.90 & 1.04 & 1.06 & 1.47 \\
Average & 2.88 & 2.02 & 1.66 & 1.19 & 2.00 & 2.19 \\
\hline
\end{tabular}


Table 19. Distances (in kilometers) and directions of sampling locations (Fig. 6) from LLNL and TRL stacks, and predicted and measured tritium concentrations in air at the LLNL site boundary for the years 1989 to 1991 . See Table 16 for LLNL (Bldg. 331) and Sandia (TRL) stack parameters.

\begin{tabular}{lllllll}
\hline $\begin{array}{c}\text { Distance } \\
(\mathrm{km}) \text { from }\end{array}$ & SALV & MESQ & \multicolumn{1}{c}{ CAFE } & MET & VIS & COW \\
\hline Bldg. 331 & $0.8 \mathrm{ESE}$ & 0.9 WNW & $0.4 \mathrm{~S}$ & $1.32 \mathrm{NNW}$ & $1.0 \mathrm{ENE}$ & $1.3 \mathrm{NNE}$ \\
TRL & $0.9 \mathrm{NE}$ & $1.7 \mathrm{NW}$ & $0.75 \mathrm{~N} / \mathrm{NNW}$ & $2.3 \mathrm{NNW}$ & $1.62 \mathrm{NNE}$ & $2.2 \mathrm{NE}$
\end{tabular}

Tritium concentrations in air $\left(\mathrm{Ci} / \mathrm{m}^{3}\right)$

\begin{tabular}{|c|c|c|c|c|c|c|}
\hline & SALV & MESQ & CAFE & MET & VIS & cow \\
\hline \multicolumn{7}{|c|}{ 1989, calculated } \\
\hline TRL & 4.16E-11 & $1.16 \mathrm{E}-11$ & $1.89 \mathrm{E}-11$ & 8.32E-12 & $2.43 E-11$ & $1.82 \mathrm{E}-11$ \\
\hline LLNL & $1.96 \mathrm{E}-11$ & 1.23E-11 & 5.42E-11 & 8.87E-12 & $6.16 \mathrm{E}-11$ & $4.98 \mathrm{E}-11$ \\
\hline Total & $6.12 \mathrm{E}-11$ & $2.40 \mathrm{E}-11$ & 7.31E-11 & 1.72E-11 & 8.59E-11 & $6.80 \mathrm{E}-11$ \\
\hline \multicolumn{7}{|c|}{ 1989, measured } \\
\hline & $3.20 \mathrm{E}-11$ & 2.20E-11 & $3.20 \mathrm{E}-11$ & 8.00E-12 & $3.20 \mathrm{E}-11$ & $1.80 \mathrm{E}-11$ \\
\hline \multicolumn{7}{|c|}{1990 , calculated } \\
\hline TRL & 1.55E-11 & $2.09 \mathrm{E}-12$ & $4.95 \mathrm{E}-12$ & $1.16 \mathrm{E}-12$ & $6.81 E-12$ & $5.42 \mathrm{E}-12$ \\
\hline LLNL & 1.35E-11 & $1.07 E-11$ & $1.42 \mathrm{E}-11$ & $4.22 \mathrm{E}-12$ & 3.11E-11 & 2.13E-11 \\
\hline Total & 2.90E-11 & 1.27E-11 & $1.92 \mathrm{E}-11$ & $5.38 \mathrm{E}-12$ & $3.79 \mathrm{E}-11$ & 2.67E-11 \\
\hline \multicolumn{7}{|c|}{ 1990, measured } \\
\hline & $1.63 \mathrm{E}-11$ & $1.04 \mathrm{E}-11$ & $1.84 \mathrm{E}-11$ & $6.60 \mathrm{E}-12$ & $1.77 E-11$ & $1.03 \mathrm{E}-11$ \\
\hline \multicolumn{7}{|c|}{ 1991, calculated } \\
\hline TRL & 2.33E-11 & $5.55 \mathrm{E}-12$ & $1.24 \mathrm{E}-11$ & 3.27E-12 & 1.22E-11 & $8.32 \mathrm{E}-12$ \\
\hline LLNL & $9.46 \mathrm{E}-12$ & $5.16 \mathrm{E}-12$ & 2.13E-11 & $6.66 \mathrm{E}-12$ & 2.92E-11 & $2.56 \mathrm{E}-11$ \\
\hline Total & $3.28 \mathrm{E}-11$ & 1.07E-11 & $3.37 \mathrm{E}-11$ & $9.94 \mathrm{E}-12$ & 4.14E-11 & $3.39 \mathrm{E}-11$ \\
\hline \multicolumn{7}{|c|}{ 1991, measured } \\
\hline & 1.43E-11 & $1.22 \mathrm{E}-11$ & $1.88 \mathrm{E}-11$ & 8.57E-12 & $1.23 E-11$ & $1.02 \mathrm{E}-11$ \\
\hline
\end{tabular}


Table 20. Predicted-to-measured tritium concentration ratio for on-site tritium sampling stations.

\begin{tabular}{lcccccc}
\hline Year & SALV & MESQ & CAFE & MET & VIS & COW \\
\hline 1989 & 1.91 & 1.09 & 2.29 & 2.15 & 2.69 & 3.78 \\
1990 & 1.78 & 1.23 & 1.04 & 0.81 & 2.14 & 2.59 \\
1991 & 2.29 & 0.88 & 1.79 & 1.16 & 3.37 & 3.32 \\
Average & 1.99 & 1.06 & 1.71 & 1.37 & 2.73 & 3.23 \\
\hline
\end{tabular}

\section{B. Tritiated Water Vapor Emissions}

In the calculations we assumed $100 \% \mathrm{HTO}$ for routine atmospheric tritium emissions. Experience at LLNL and SNL suggests that this assumption is fairly conservative (see Table 21), causing us to overestimate tritium exposures in the Livermore Valley.

Table 21. Historical tritiated-water-vapor (HTO) to total-tritium-emission ratio for LLNL and SNL.

\begin{tabular}{lc}
\hline Year & $\begin{array}{c}\text { Tritiated/total } \\
\text { emission }\end{array}$ \\
\hline 1986 & 0.70 \\
1987 & 0.41 \\
1988 & 0.48 \\
1989 & 0.58 \\
1990 & 0.60 \\
1991 & 0.65 \\
Average & 0.57 \\
\hline
\end{tabular}

\section{Ingestion Pathway}

In the tritium dose calculations, the tritium specific activity in vegetation was assumed to be in equilibrium with the atmospheric water. Vegetation- and air-monitoring data for the Livermore Valley (see Figs. 7 and 8) indicate that this is a fairly valid assumption based. No soil data are available near the vegetation- or airmonitoring stations, but there is one area close to the MET tower sampling station that can be used to relate the tritium activity in vegetation to that in soil (see Fig. 9). At this location, the tritium activity in the soil water is appreciably lower than that in the ve etation water. One can therefore conclude with some confidence that uptake of tritium in vegetation (grass) occurs primarily from the tritiated water vapor in the atmospheric air.

Based on these studies, it is reasonable to assume that tritium specific activity is in equilibrium with the water content in leaves of vegetation. This is consistent with the average ratio of 0.8 between water content of vegetation and water vapor content of air observed at the Savannah River Laboratory (Murphy, 1984). 
(a)

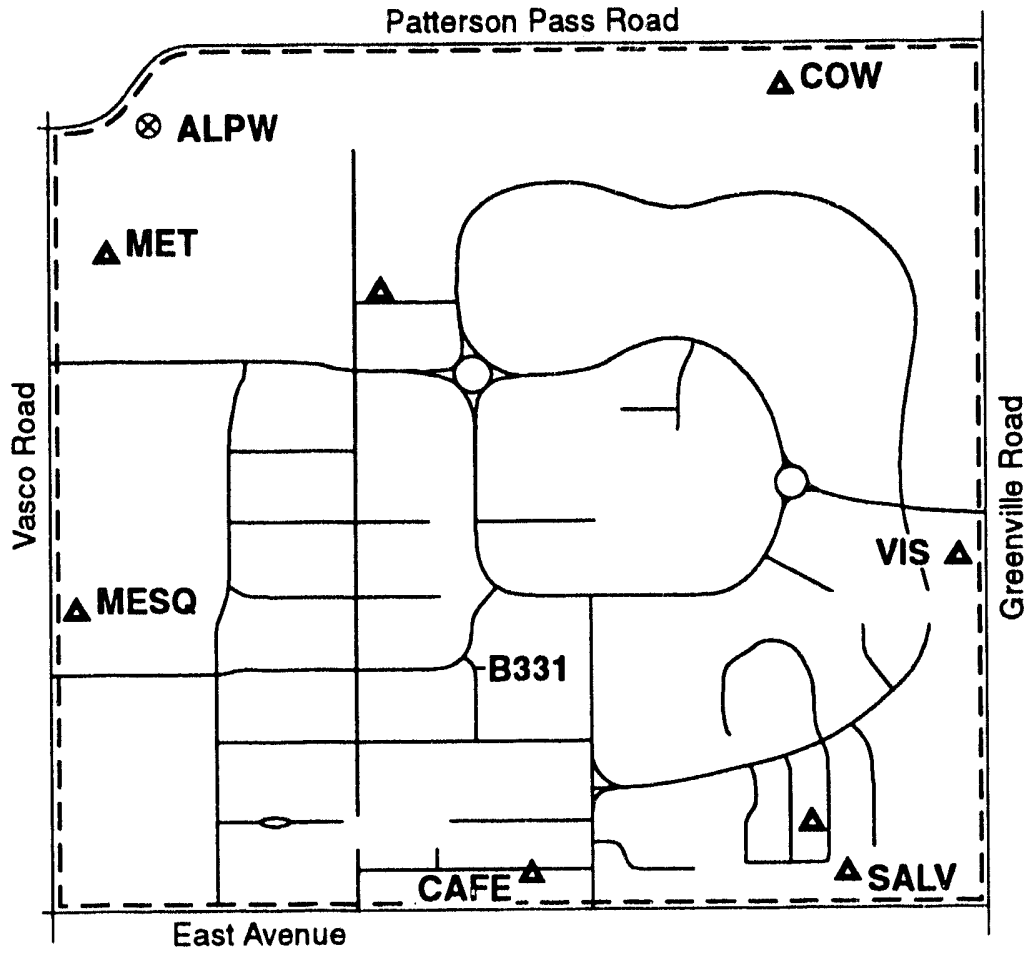

Tritium research laboratory (Sandia)
- - LLNL perimeter

$\Delta$ Tritium sampling locations

$\otimes$ Soil sampling location

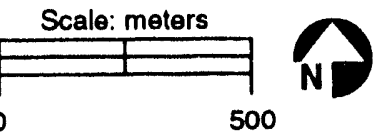

(b)
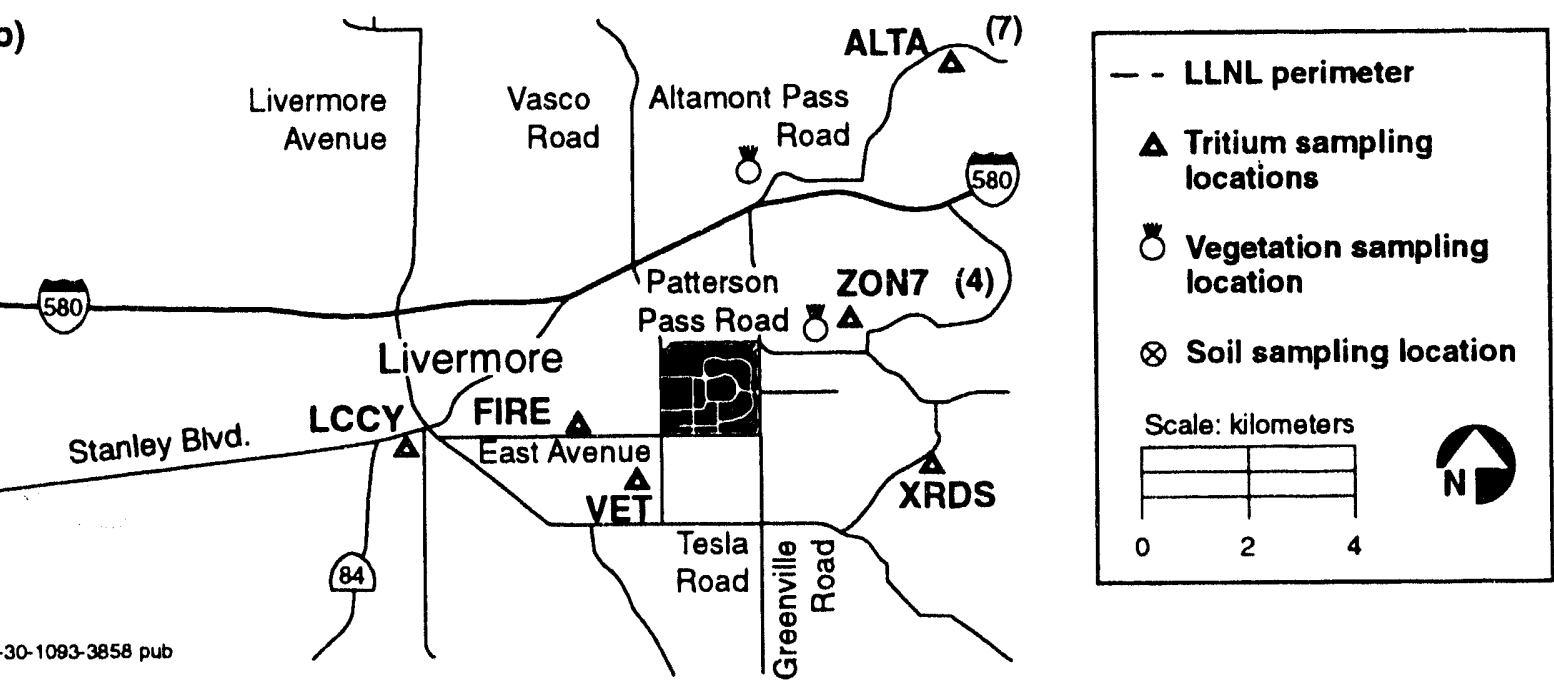

02-30-1093-3858 pub

Figure 6. Tritium sampling locations (LLNL Annual Environmental Report, 1992). (a) LLNL site.

(b) LLNL vicinity. 


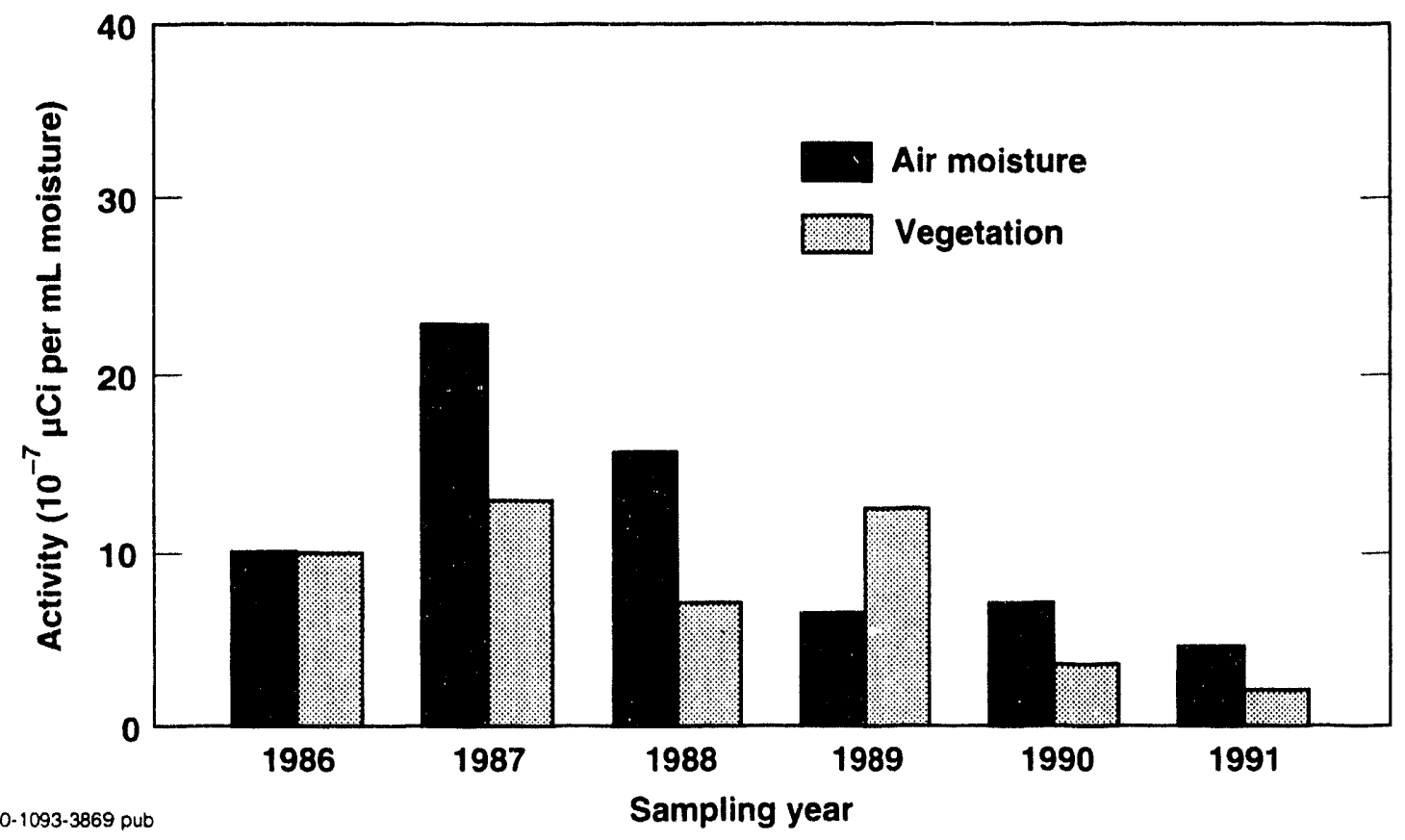

Figure 7. Tritium activity in water content of air at location 7 (Altamont Pass Road; Fig. 6b) and in vegetation near Interstate Highway 580 for years 1986 through 1991.

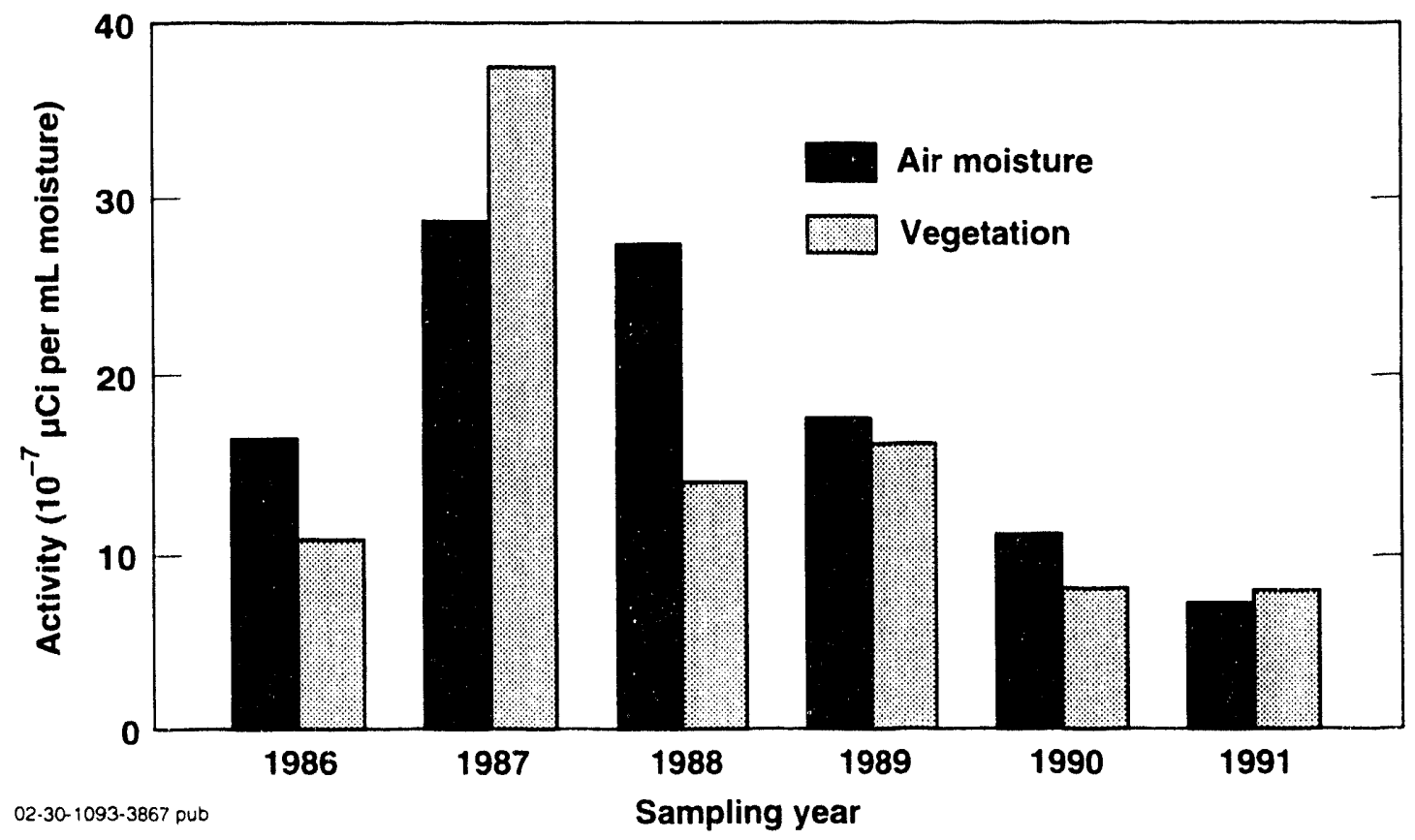

Figure 8. Tritium activity in water content of air and vegetation (grass) at location 4 (Patterson Pass Road; Fig. 6b) for years 1986 through 1991. 


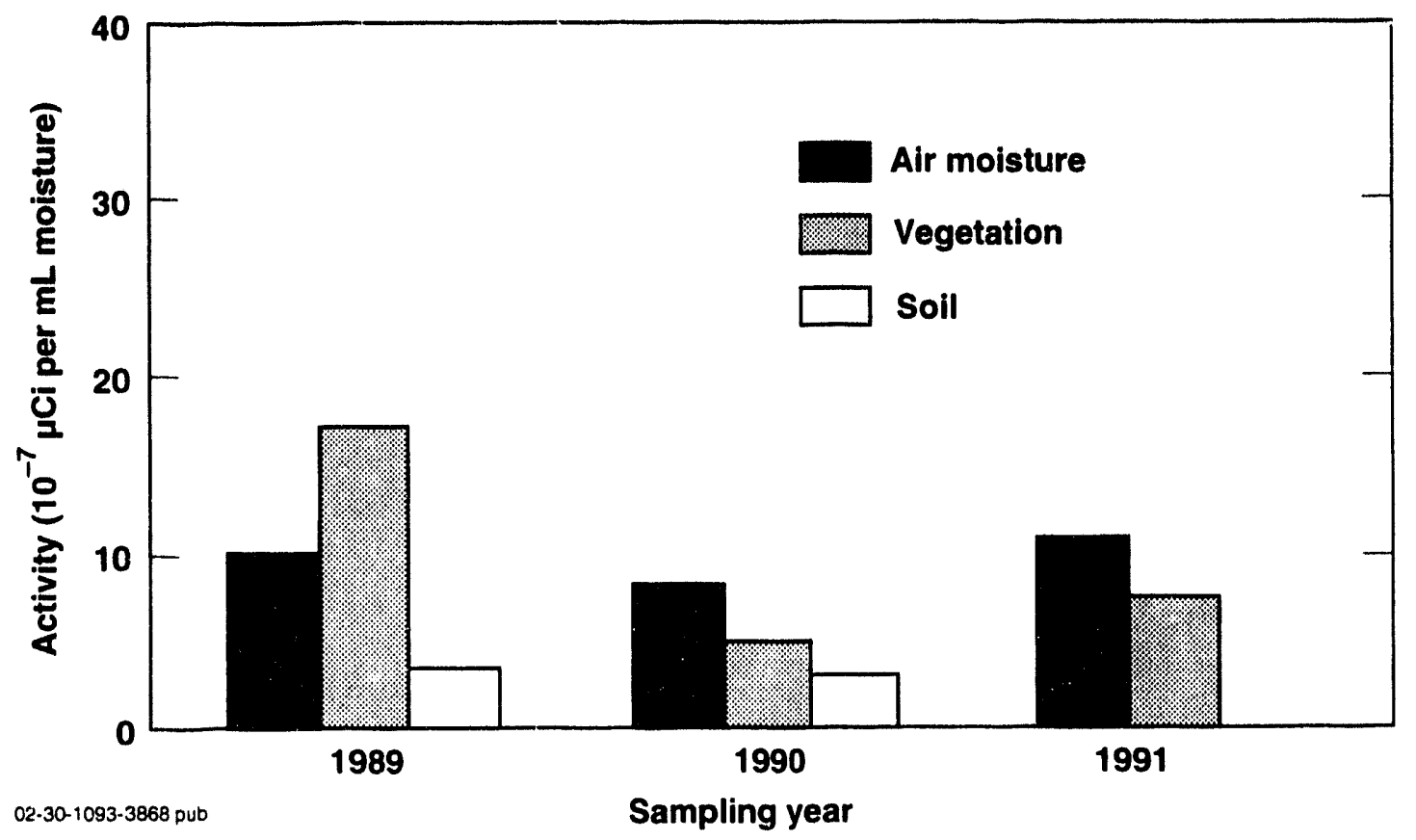

Figure 9. Tritium activity in water content of air, vegetation (grass), and soil near MET tower (ALPW; Fig. 6a) for years 1989 through 1991. 


\section{Benchmark Shielding Calculations and Measurements for Deep Penetration of DT Neutrons in Concrete}

The neutron and secondary gamma-ray radiation intensity predicted outside the NIF experiment area were calculated using Monte Carlo procedures. The complexity of nuclear collisions and secondary productions and their subsequent multiple scattering makes it difficult to have a great deal of confidence in the predicted results, particularly for 2- to 3-m-thick concrete shields. To bracket the uncertainty, we performed benchmark calculations and compared the results with measurements made at RTNS-II. Based on these benchmark studies, we find that the calculated dose equivalents for 2.13- and 2.44-m-thick concrete shields are overpredicted by about a factor of 2, a fairly good agreement considering the complexity of nuclear interactions. Details of our benchmark studies are presented below.

\section{A. 400-keV Deuteron Accelerator (RTNS-II)}

From 1978 to 1989 , the RTNS-II accelerator was dedicated to fusion materials research in the Magnetic Fusion Energy program. To improve the fusion material research program, Panel 5 of the Fusion Energy Advisory Committee (FEAC) has encouraged the United States to participate in the development of an international $14-\mathrm{MeV}$ neutron source. The construction of this facility will probably begin in 1996 . Although the data presented in this section have direct bearing on NIF, they are equally relevant for validating transport codes used for the design of shielding for fusion reactors or devices or for intense 14- $\mathrm{MeV}$ neutron sources.

At RTNS-II, the bombardment of a tritium target by $400-\mathrm{keV}$ deuterons provides a continuous source of $10^{13} 14-\mathrm{MeV}$ neutrons per second. Experimental data (Logan, 1992) indicate that the mean energy of the deuterons that interact with tritium nuclei is about $200 \mathrm{keV}$. Figure 10 shows the expected dependence of neutron energy on emission angle, calculated with the relativistic energy-momentum relations of Blumberg and Schlesinger (Blumberg and Schlesinger, 1956) for the $D(T, n)^{4}$ He reaction. The classical approximation for 200-keV deuterons interacting with tritons gives about the same energy-angle correlations.
Figure 10 shows that the calculated neutron energy agrees quite well with the measurements at $30^{\circ}$ and $120^{\circ}$ with respect to the incident deuteron direction (Logan and Komoto, 1992). On the strength of this agreement, we used $15.1-\mathrm{MeV}$ neutrons in the forward direction and $14.1-\mathrm{MeV}$ neutrons at $90^{\circ}$ for the benchmark calculations. RTNS-II consists of two identical machine rooms and target cells. The exterior concrete walls of the target cells are $2.44 \mathrm{~m}$ thick; the concrete roof is $2.13 \mathrm{~m}$ thick. The common (middle) concrete wall between the cells is $2.13 \mathrm{~m}$ thick. Both cells have 2.44-m-thick concrete doors. The doors were designed to minimize neutron leakage; there are three $10-\mathrm{cm}$ steps on each vertical side and on top of the door with $1.27-\mathrm{cm}$ maximum clearance; the bottom is sloped to give a $15-\mathrm{cm}$ depression over the width of the door with $0.64-\mathrm{cm}$ clearance. Figure 11 shows the 2.44 -m-thick door and inside of target area. The interior dimensions of each target cell are $6.1 \times 6.5 \times 4.27 \mathrm{~m}$.

During the initial runs, only one accelerator was used, so it was possible to make neutron and gamma-ray spectrometry and dose/flux measurements in the adjacent cell and outside the door. Figure 12 shows the locations at which these measurements were made.

\section{B. Flux Measurement Methods}

The neutron flux measurements were made with the De Pangher "precision long counter" (PLC) (De Pangher, 1966). The PLC's neutronenergy response from 0.002 to $20 \mathrm{MeV}$ was measured very precisely at LLNL (Slaughter and Rueppel, 1977). The relative response of the PLC is fairly flat from 0.4 to $14 \mathrm{MeV}$, but it underresponds for neutron energies below a few keV. The thermal neutron component is effectively absorbed by a Cd shield in the detector. The counter's nominal sensitivity to fast neutrons was verified with PuBe and ${ }^{252} \mathrm{Cf}$ neutron sources. During the neutron flux measurements at RTNS-II, the PLC calibration was periodically confirmed in the field with a PuBe source. We also used NE-213 liquid scintillator to measure the neutron spectrum, but because of high noiseto-signal ratio, this data was not used for quantitative purposes. 


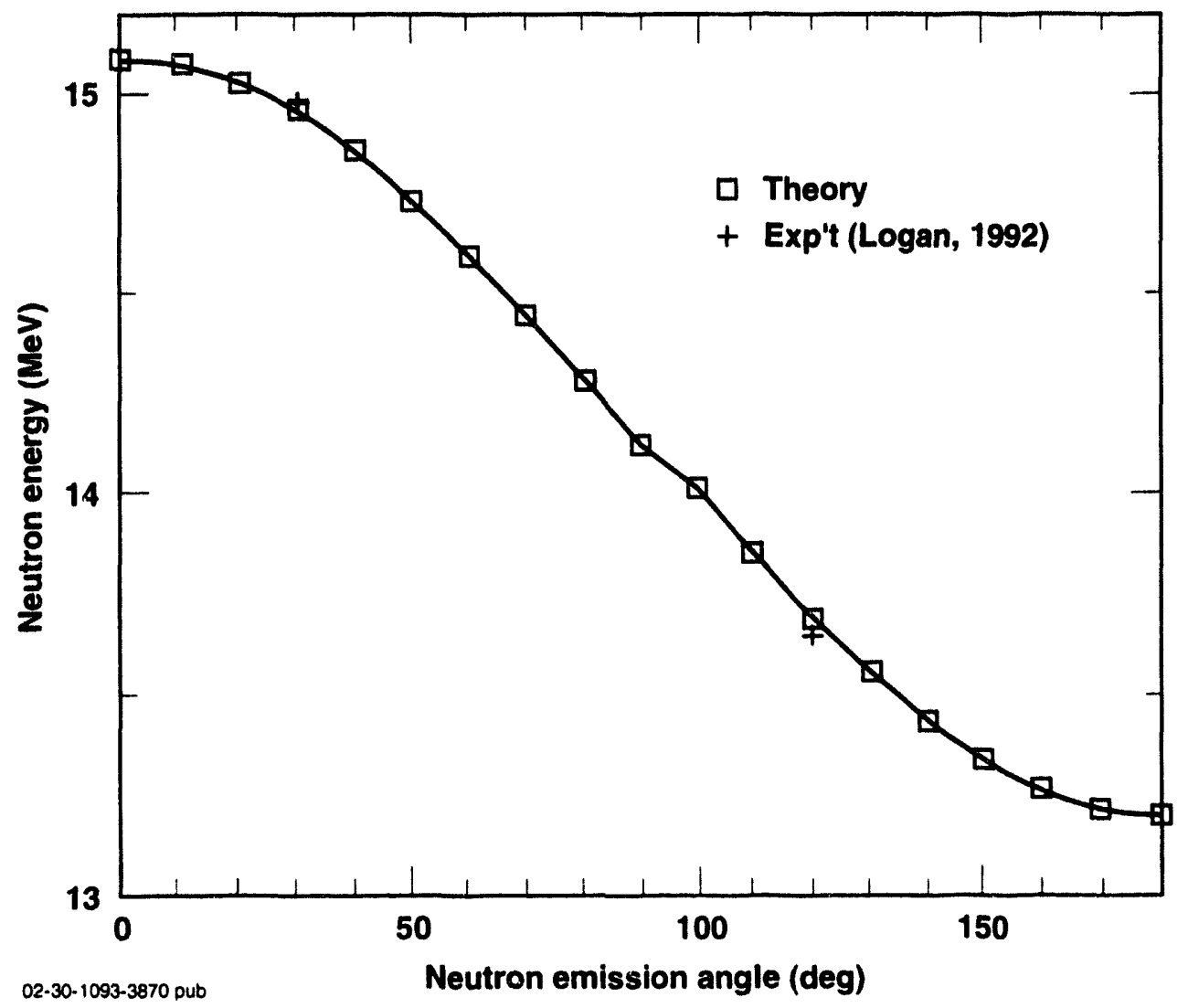

Figure 10. DT neutron energy vs emission angle for $200-\mathrm{keV}$ deuteron interaction with tritium.

The photon flux outside the 2.13-m-thick shield was determined from pulse-height data taken with a $3 \times 3 \mathrm{NaI}(\mathrm{Tl})$ detector. Because of low photon intensity, the measurements were accumulated over $10^{4}$-sec intervals. Livermore computer programs (Fuess et al., 1978) were used to convert the experimental pulse-height data to a differential photon energy spectrum, which was then used to calculate dose equivalents. These data were used as a reference for calibrating an ion chamber (STRAD) and micro-R meter, which were used for rapid photon intensity measurements at other locations.

\section{Results}

Figure 13 shows the calculated neutron spectrum outside the 2.13 -m-thick concrete shield. Table 22 gives the elemental composition of the concrete mix, determined by chemical analysis. The theoretical broad peak between 1 and $4 \mathrm{MeV}$ shown in Fig. 13 was observed with a NE-213 liquid scintillator (see inset in Fig. 13). This peak is due to depression in neutron cross section in concrete in this energy range. The calculated spectrum-weighted flux-to-dose conversion factor for transmitted neutrons with energies from 0.001 to $14 \mathrm{MeV}$ was $1.2 \times 10^{-4} \mathrm{rem} / \mathrm{h}$ per $\mathrm{n} / \mathrm{cm}^{2} \cdot \mathrm{s}$, about the same as what we calculated for the ${ }^{252} \mathrm{Cf}$ neutrons $\left(1.25 \times 10^{-4} \mathrm{rem} / \mathrm{hr}\right.$ per $\left.\mathrm{n} / \mathrm{cm}^{2} \cdot \mathrm{s}\right)$. The thermal flux was based on the thermalneutron sensitivity of the $\mathrm{BF}_{3}$ counter. Based on theoretical calculations coupled with experimental measurements with a bare $\mathrm{BF}_{3}$ tube, we estimate that the neutron dose contribution for energies below $0.001 \mathrm{MeV}$ is about $18 \%$. Table 23 gives the theoretical and experimental results. Figure 14 shows the variation of attenuation with concrete thickness. Experimental measurements indicate that the theory overpredicts the dose equivalent outside the concrete shield by a factor of 2 . Figure 15 shows the calculated and measured differential photon energy spectrum 


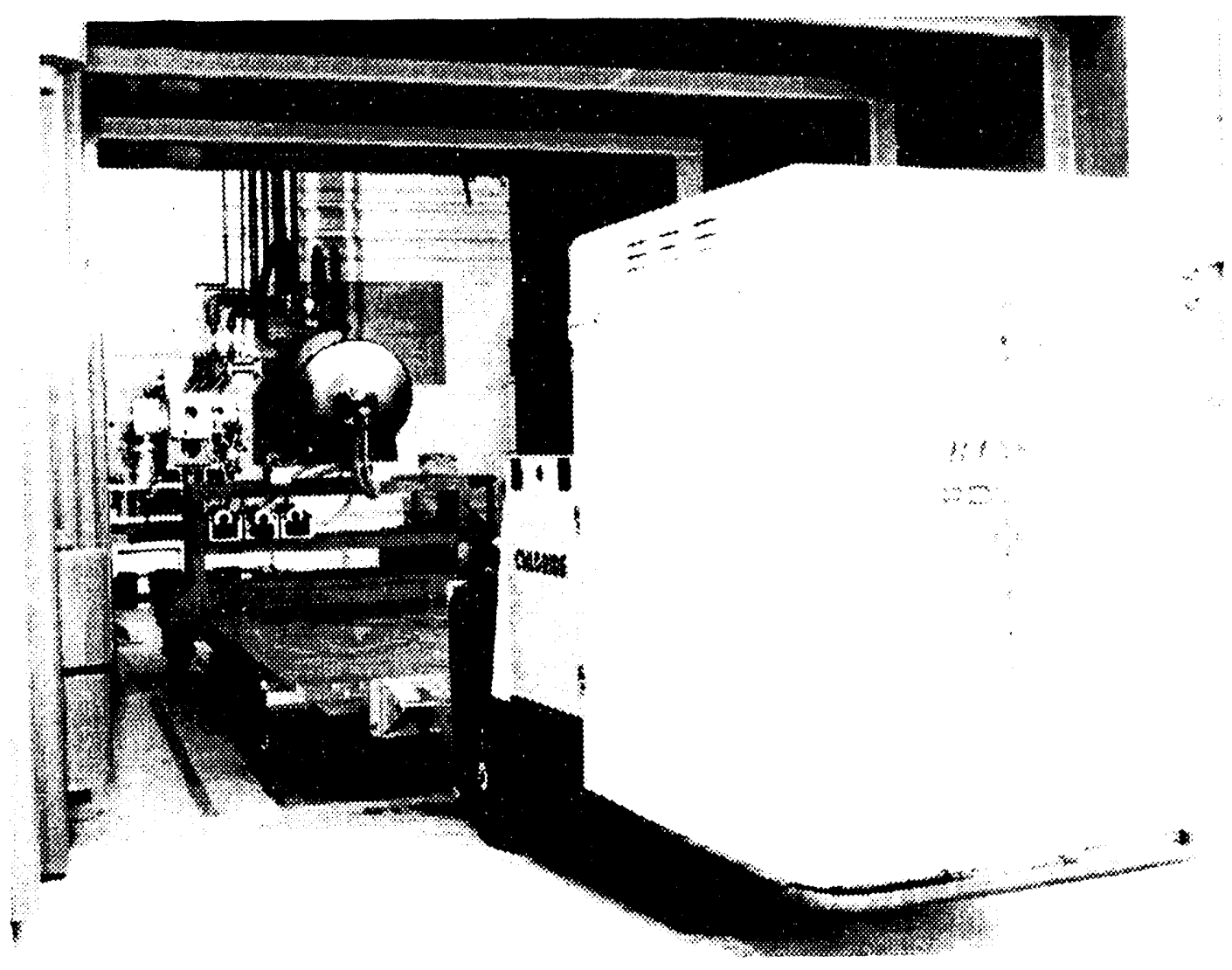

Figure II, RINS-II larget room.

Iable 22. Hemental componition of I ivermore concrete mix.

\begin{tabular}{|c|c|}
\hline Hement & Atomic fraction \\
\hline HI & 0.119 .3 \\
\hline () & 0.6062 \\
\hline $\mathrm{He}$ & 0.1220 \\
\hline $\mathrm{Ng}$ & $1.226 \mathrm{E}-2$ \\
\hline$A 1$ & $3.181-2$ \\
\hline $\mathrm{Na}$ & $2.2361-2$ \\
\hline Si & 0.1752 \\
\hline ca & $2.99851-2$ \\
\hline
\end{tabular}

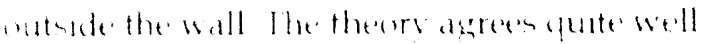
with the aberersed hape of the greetrum

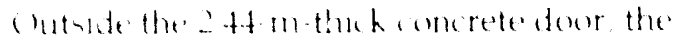

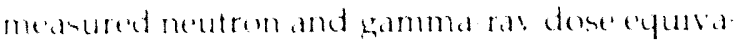

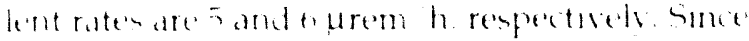

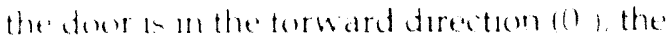
modent neutronenerge is $15.1 \mathrm{Me}$. an described Abure At low deuteron hombarding energy

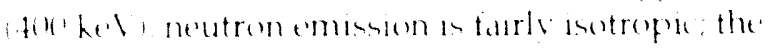

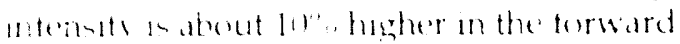
direntem than at at Figure 14 indicaten that the

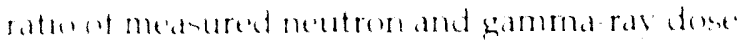

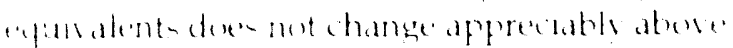

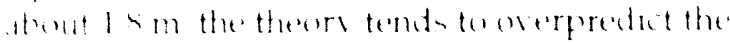

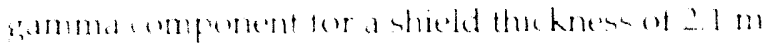


Table 23. Neutron and secondary gamma-ray intensity outside the 2.13-m-thick shielding wall. All results were normalized to RTNS-II neutron source strength $\left(10^{13}\right.$ DT neutrons per second). Figure 12 shows locations tabulated here.

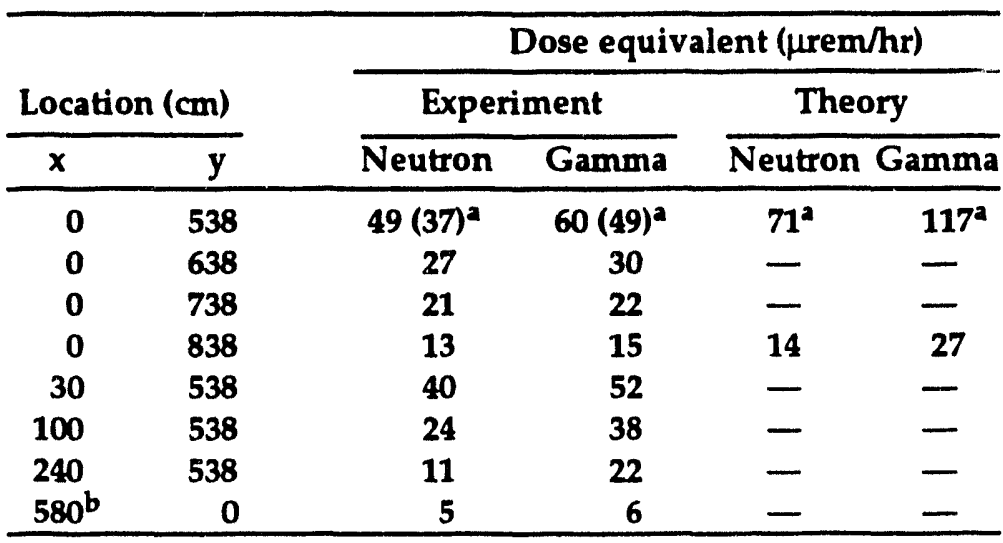

Dose rate averaged over an area with $100-\mathrm{cm}$ radius.

b Dose equivalents outside the RTNS-II 2.44-m-thick concrete shiel ding door.

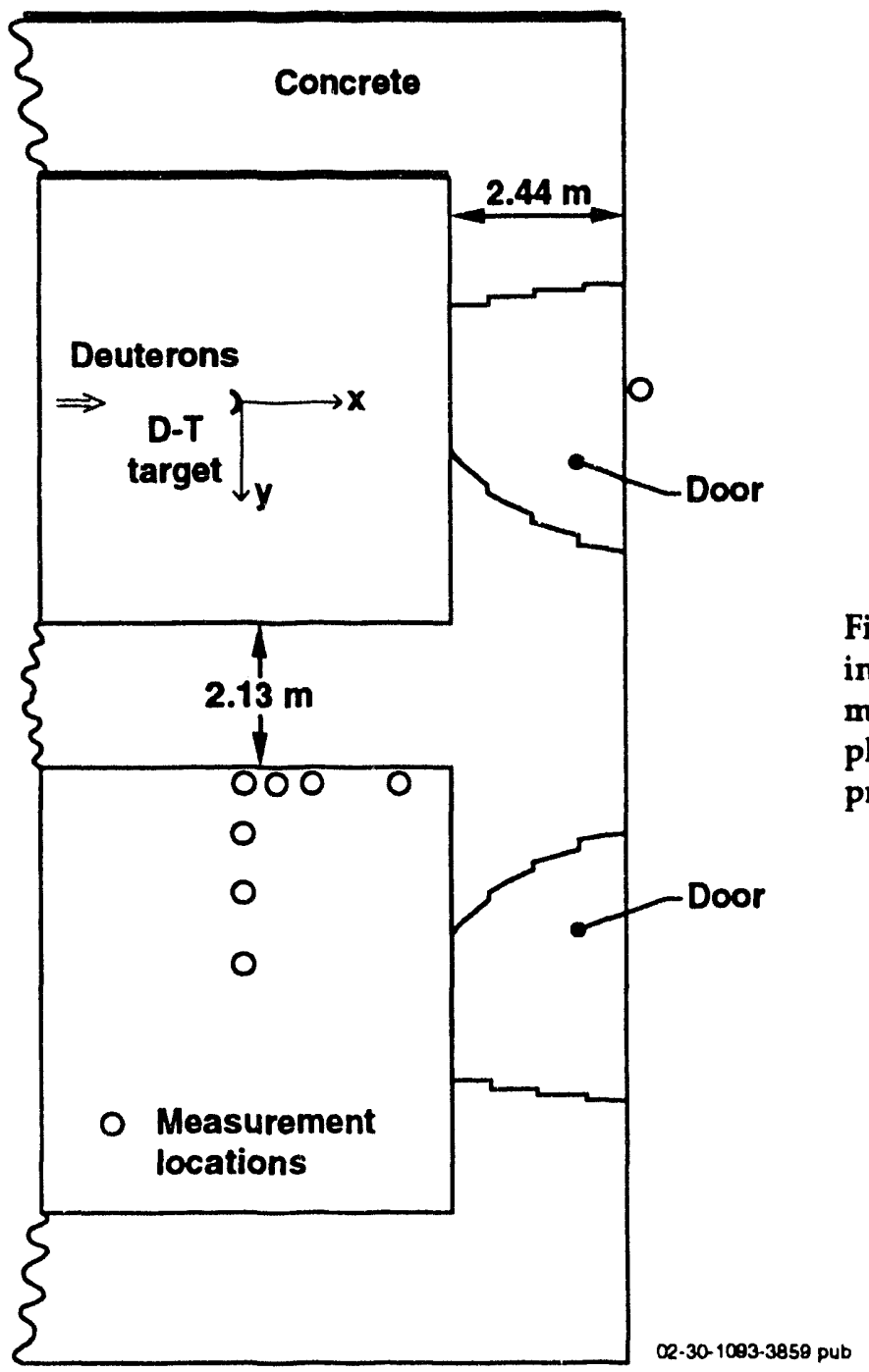

Figure 12. Neutron and secondary gamma intensity measurement locations (plan view). All measurements were made in the horizontal plane containing the target; Table 23 gives precise locations. 


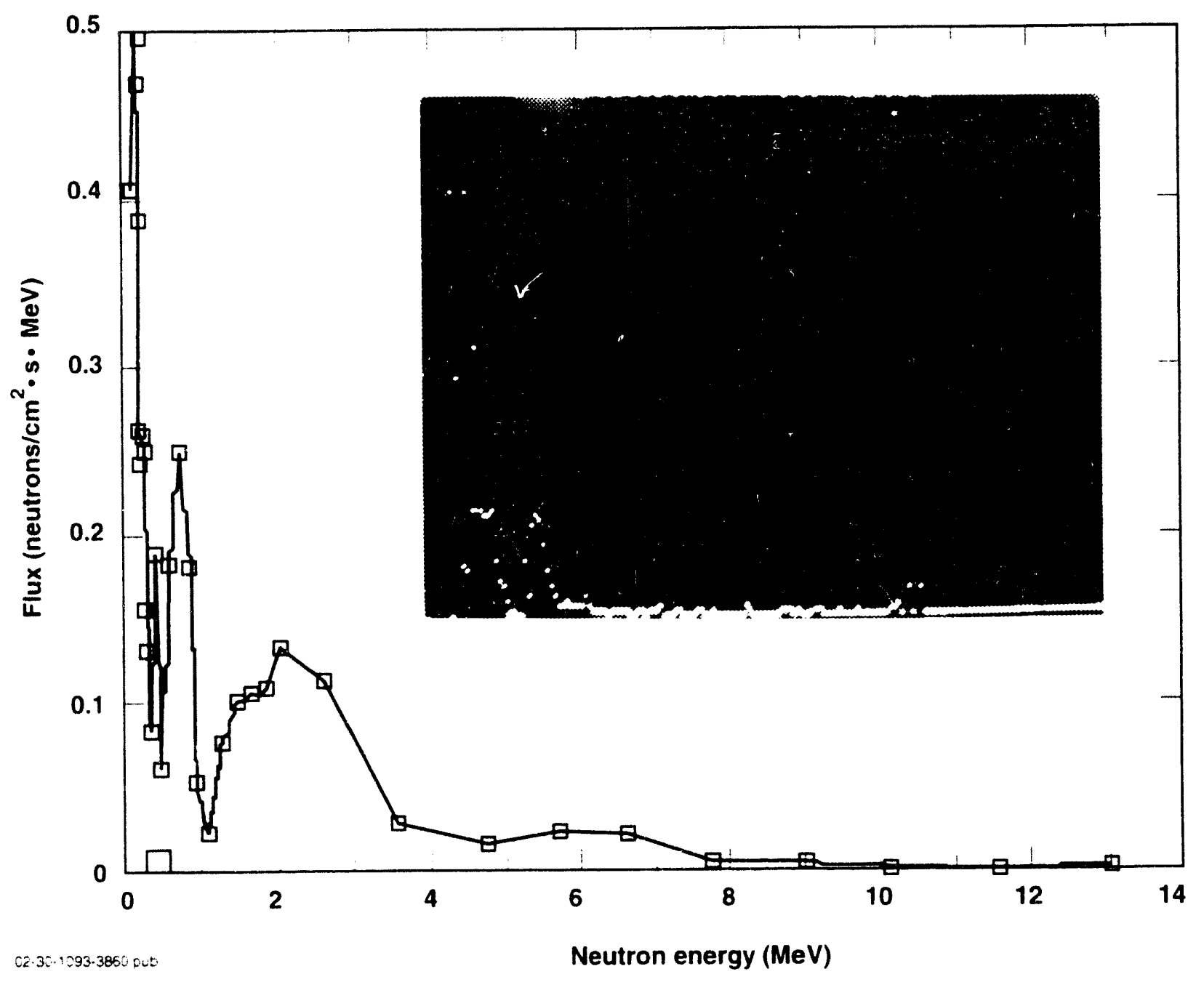

Figure 13. Calculated neutron spectrum outside the RTNS-II 2.13-m-thick concrete shielding wall. Inset: neutron spectrum measured with NE-213. 


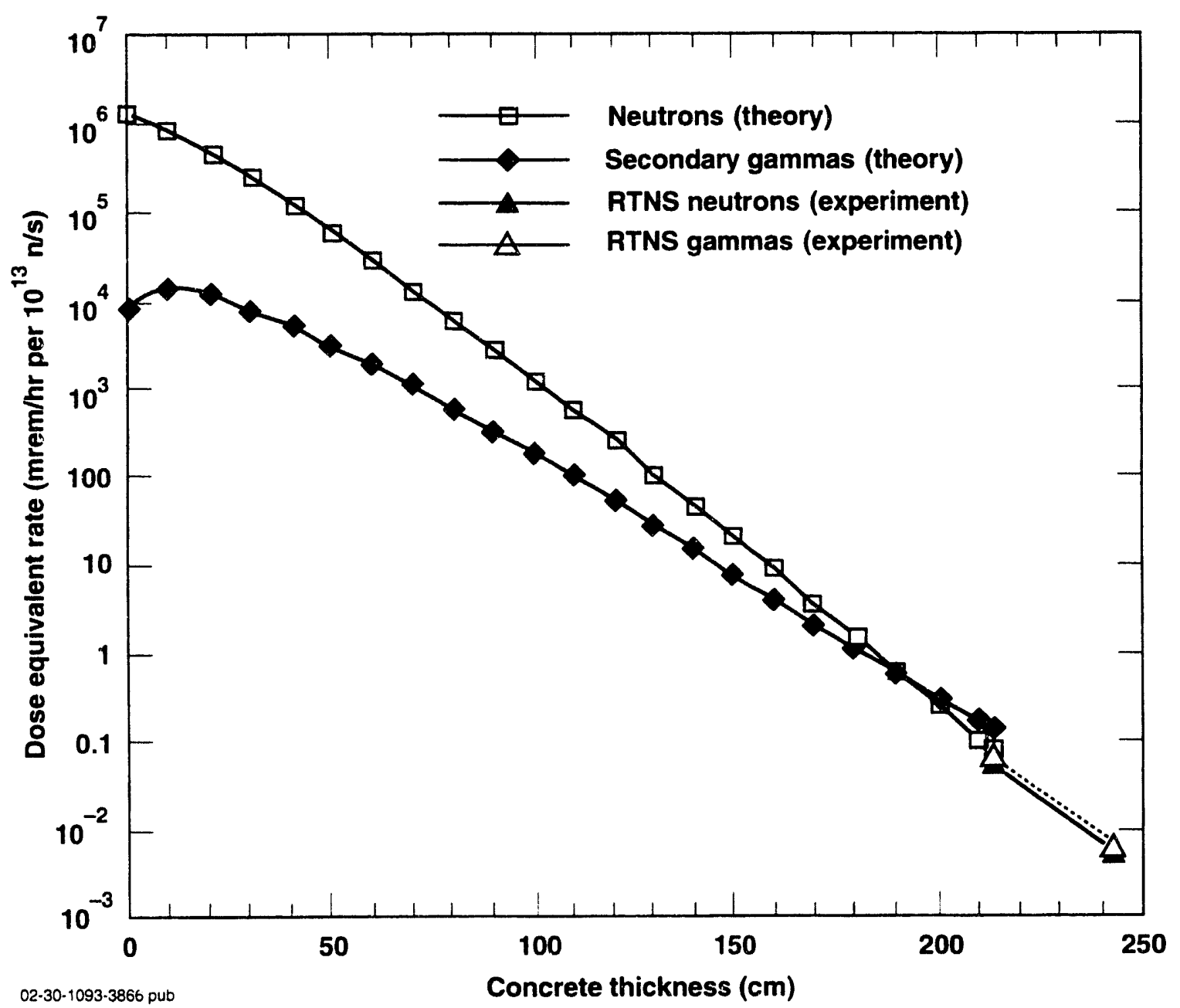

Figure 14. Attenuation of 14-MeV neutrons and secondary gamma rays through an ordinary concrete shield. The dose equivalent rates are normalized to $10^{13} \mathrm{n} / \mathrm{s}$, the level at which RTNS-II was operating during the measurements. 


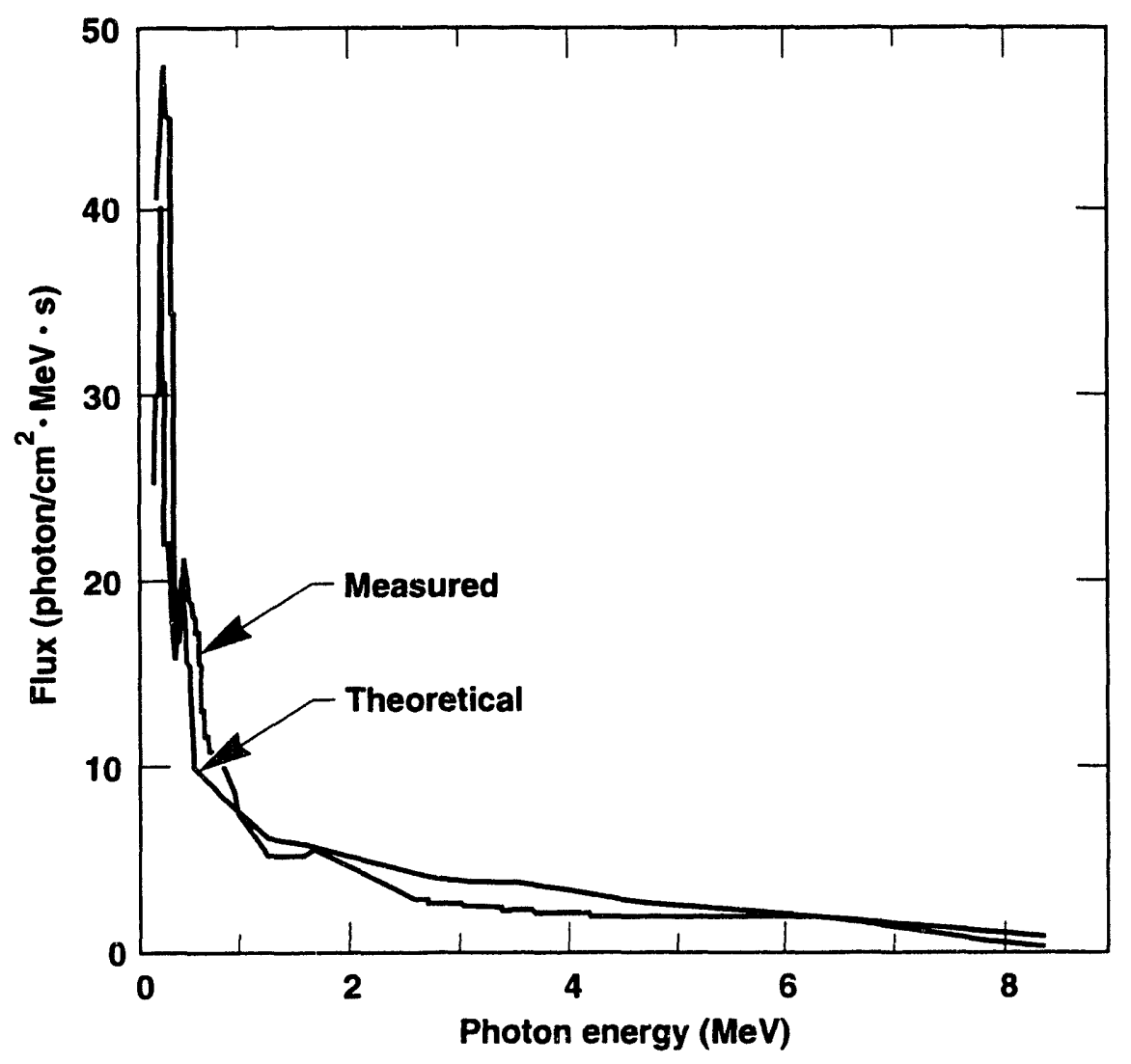

$02 \cdot 30 \cdot 1093-3861$

Figure 15. Calculated and measured photon spectrum outside the RTNS-II 2.13-m-thick concrete shielding wall. 


\section{Acknowledgments}

I thank E. M. Campbell, Acting Associate Director for Laser and Environmental Programs, for his valuable comments on the manuscript and for his suggestion to publish the report. I am grateful to J. M. Yatabe, D. S. Myers, M. T. Tobin, D. Brekke (Sandia Naticnal Laboratories, Livermore), C. D. Henning, W. H. Lowdermilk, D. W. Rueppel, J. Stencel (Plasma Physics Labo:atory, Princeton University), C. W. Hatcher and S. J. Brereton for their thorough review of the manuscript. I thank P. W. Murphy for superb editorial assistance and my daughter Rup for converting and rekeying the tables. I am grateful to $T$. J. Gilmartin for reviewing the final manuscript. 


\section{References}

Blumberg, L., and Schlesinger, S. I., 1956, Relativistic Tables of Energy and Angle Relationships for the $\mathrm{T}(p, n)^{3} \mathrm{He}, \mathrm{D}(d, n)^{3} \mathrm{He}$ and $\mathrm{T}(d, n)^{4} \mathrm{He}$ Reactions, Los Alamos National Laboratory, Los Alamos, NM, AECU-3118.

Brekke, D., 1992, Sandia National Laboratories, Livermore, CA, personal communication.

Campbell, E. M., Hogan, W. J., and Lowdermilk, W. H., 1992, "Nova Upgrade Mission and Design," Fusion Technology 21, 1344-1348.

De Pangher, J., and Nichols, L. L., 1966, A Precision Long Counter for Measuring Fast Neutron Flux Density, Pacific Northwest Laboratory, Richland, WA, BNWL-260.

Educational Data Services, 1991, Baseline 1990 Census, Lawrence Livermore National Laboratory. (Tim Parnell, Weston Co., personal communication, June $17,1992$.

Fuess, D. A., Slaughter, D. R., Strought, R. E., and Rueppel, D. W., 1978, Determination of Continuous Gamma-Ray Spectra over the Energy Range 0.1 to $8 \mathrm{MeV}$, Lawrence Livermore National Laboratory, Livermore, CA, UCRL-52513.

Gouveia, F. J., 1992, Lawrence Livermore National Laboratory, Livermore, CA, personal communication.

Guthrie, E. B., 1992, Lawrence Livermore National Laboratory, Livermore, CA, personal communication.

Huguet, M., et al., 1992, "Technical Aspects of the First JET Tritium Experiment," Fusion Engineering and Design 19, 121-131.

International Commission on Radiological Protection, 1991, 1990, Recommendations of the International Commission on Radiological Protection, ICRP Publication 60, Annex B, Table B-20 (Pergamon Press, Oxford).

Lamson, K. C., Gouveia, F. J., and Rueppel, D. W., 1992, Lawrence Livermore National Laboratory, Livermore, CA, personal communication.

Latkowski, J., and Tobin, M., 1993, Safety Issues Related to Neutronics for the National Ignition Facility, Inertial Confinement Fusion Program, Lawrence Livermore National Laboratory, Livermore, $\mathrm{CA}$, internal document 93-001.
Lawrence Livermore National Laboratory, 19861991, Environmental Reports, Lawrence Livermore National Laboratory, Livermore, CA, UCRL-50027-86 to 92.

Logan, C. M., 1992, Lawrence Livermore National Laboratory, Livermore, CA, personal communication.

Logan, C. M., and Komoto T. T., 1992, "Observed Penetration of $14-\mathrm{MeV}$ Neutrons in Various Materials," submitted to Nuclear Science and Engineering.

Moore, D. H., 1993, Lawrence Livermore National Laboratory, Livermore, CA, personal communication.

Murphy, C. E., 1984, "The Relationship Between Tritiated Water Activities in Air, Vegetation and Soil under Steady-State Conditions," Health Phys. 47, 635-639.

National Academy of Sciences, 1980, The Effects on Populations of Exposure to Low Levels of Ionizing Radiation (National Academy Press, Washington, DC).

National Research Council, 1990, Health Effects of Exposure to Low Levels of lonizing Radiation (BEIR V), (National Academy Press, Washington, $D C$ ).

Plechaty, E. F., and Kimlinger, J. R., 1976, TARTNP: A Coupled Neutron-Photon Transport Code, Lawrence Livermore National Laboratory, Livermore, CA, UCRL-50400, Vol. 14.

Slaughter, D. R., and Rueppel, D. W., 1977 , "Calibration of a De Pangher Long Counter from $2 \mathrm{keV}$ to $19 \mathrm{MeV}$," Nucl. Instrum. Methods 145, 315-320.

State of California, 1990, 1991, 1992, California Statistical Abstract (Sacramento, CA).

U.S. Department of Energy, 1988, Radiation Protection for Occupational Workers, DOE Order 5480.11.

U.S. Department of Energy, 1990, Radiation Protection of the Public and the Environment, DOE Order 5400.5.

U.S. Environmental Protection Agency, 1992a, National Emission Standards for Emissions of Radionuclides other than Radon from Department of Energy Facilities, 40 CFR 61.92.

U.S. Environmental Protection Agency, 1992b, CAP88-PC Version 1.0; EPA 402-B-92-001. 
U.S. Environmental Protection Agency, 1992c, National Emission Standards for Emissions of Radionuclides other than Radon from Department of Energy Facilities, 40 CFR 61, Appendix E, Table 2.
Wong, M., 1989, Building 331 Tritium Sampler Verification Results, Lawrence Livermore National Laboratory, Livermore, CA, internal memorandum, May 2, 1989. 

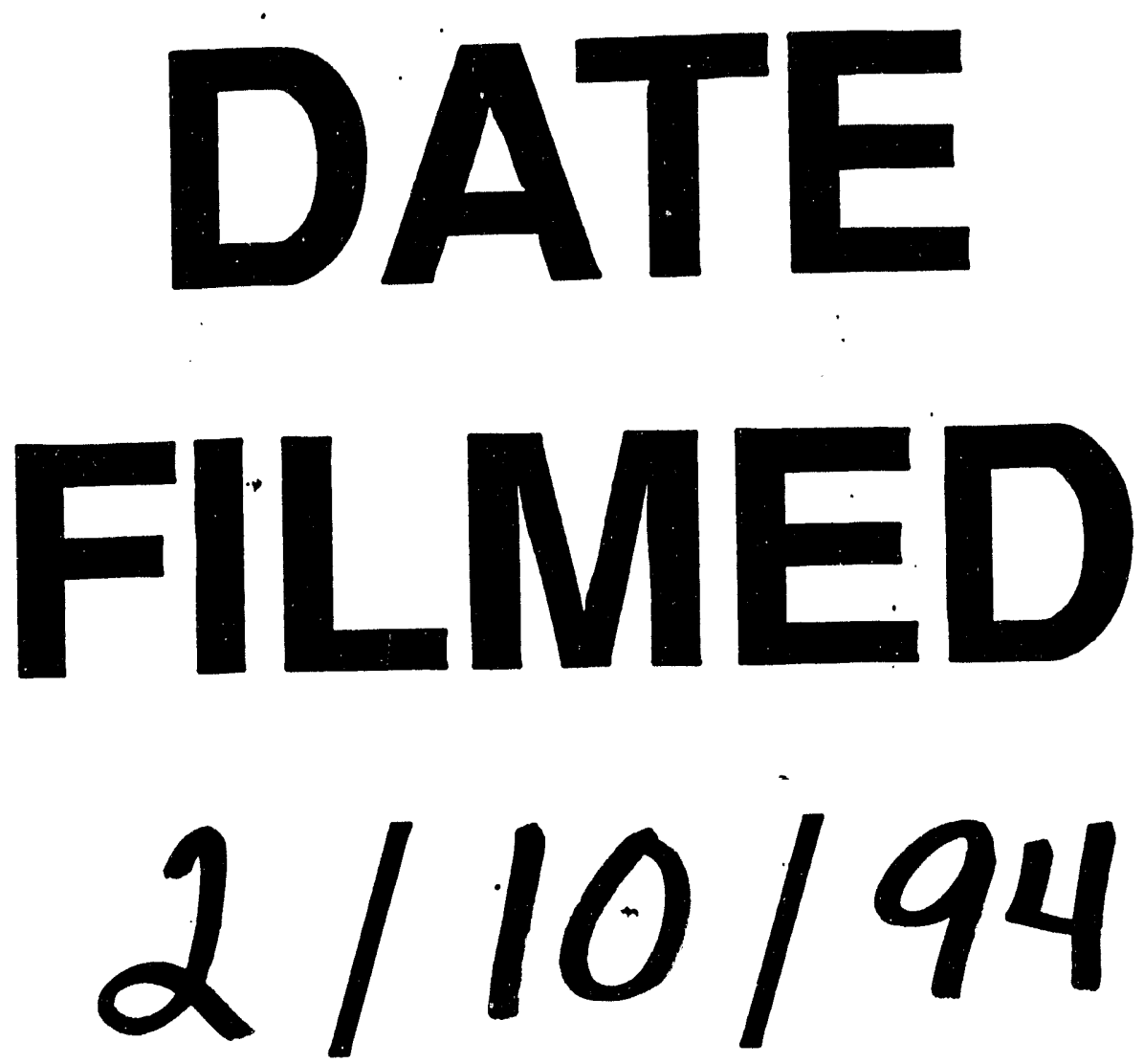

94
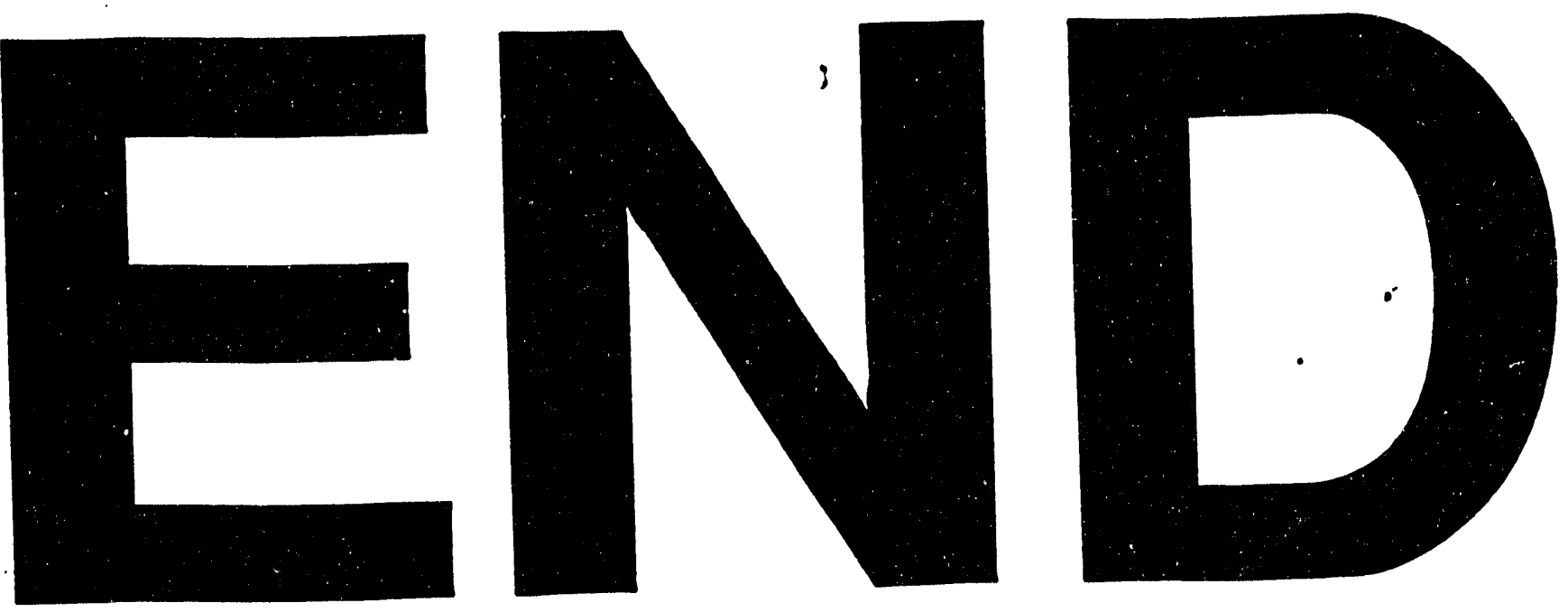


$$
\text { }
$$

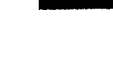

